\title{
The flow field of the subtropical gyre of the South Indian Ocean
}

\author{
L. Stramma and J. R. E. Lutjeharms ${ }^{1}$ \\ Institut für Meereskunde an der Universität Kiel, Kiel, Germany
}

\begin{abstract}
The mean state of the transport field of the subtropical gyre of the South Indian Ocean has been derived for the upper $1000 \mathrm{~m}$ from selected historical hydrographic data. The subtropical gyre in the southwestern Indian Ocean is stronger than the flow in the other two oceans of the southern hemisphere. Most of the water in the South Indian gyre recirculates in the western and central parts of the basin. In the upper $1000 \mathrm{~m}$ the eastward transport of the South Indian Ocean Current starts with $60 \mathrm{~Sv}$ in the region southeast of South Africa. Between the longitudes of $40^{\circ}$ and $50^{\circ} \mathrm{E}$ about $20 \mathrm{~Sv}$ of the $60 \mathrm{~Sv}$ recirculates in a southwest Indian subgyre. Another major diversion northward occurs between $60^{\circ}$ and $70^{\circ} \mathrm{E}$. At $90^{\circ} \mathrm{E}$ the remaining 20 $\mathrm{Sv}$ of the eastward flow splits up, $10 \mathrm{~Sv}$ going north to join the westward flow and only $10 \mathrm{~Sv}$ continuing in a northeastward direction to move northward near Australia. Near Australia, there is indication of the poleward flowing Leeuwin Current with a transport of $5 \mathrm{~Sv}$. In the central tropical Indian Ocean between $10^{\circ} \mathrm{S}$ and $20^{\circ} \mathrm{S}$, about $15 \mathrm{~Sv}$ flows to the west. The western boundary current of this subtropical gyre consists of the Agulhas Current along the east coast of southern Africa. Its mean flow is composed of $25 \mathrm{~Sv}$ from east of Madagascar and $35 \mathrm{~Sv}$ from recirculation in the southwest Indian subgyre south of Madagascar, with only $5 \mathrm{~Sv}$ being contributed from the Mozambique Channel. A net southward transport of $10 \mathrm{~Sv}$ results for the upper $1000 \mathrm{~m}$ of the South Indian Ocean. In contrast to the triangular shape of the subtropical gyre in the South Atlantic, probably caused by the cross-equatorial flow into the North Atlantic, the area influenced by the subtropical gyre in the South Indian Ocean is more rectangular.
\end{abstract}

\section{Introduction}

Due to a paucity of hydrographic data the gyral circulation of the South Indian Ocean has always been considerably less well understood than that of comparable basins such as the South Atlantic. The International Indian Ocean Expedition of the early 1960s to some extent alleviated the contemporary undersampling, but its observational program was, notwithstanding pleas to the contrary [Wüst, 1960], concentrated in the north. Increased research interest in the Somali Current [e.g., Schott and Fieux, 1985], the Agulhas Current [e.g., Gordon et al., 1987; Lutjeharms, 1987], and the Leeuwin Current [e.g., Smith et al., 1991] over the past decade has further contributed to a geographic skewing of the hydrographic data base. Consequently, it is only the

\footnotetext{
${ }^{1}$ Now at Department of Oceanography, University of Cape Town, Rondebosch, South Africa.

Copyright 1997 by the American Geophysical Union.

Paper number 96JC03455.

0148-0227/97/96JC-03455\$09.00
}

boundary regions of the South Indian that are to some extent adequately sampled.

This is particularly detrimental to an understanding of the dynamic processes of the region since it is becoming increasingly apparent that the wind-driven, anticyclonic circulation of the South Indian Ocean is considerably different than, for instance, that of the South Atlantic [Peterson and Stramma, 1991; Revd, 1994]. Reason et al. [1996] have, for example, found evidence in model results that modulations of the Indonesian throughflow can impact significantly on interdecadal variability in the South Indian Ocean.

The plates in the atlas by Wyrtkr [1971] that portray the dynamic topography of the Indian Ocean show two persistent features for the South Indian: a large, basinwide circulation and a well-developed subgyre west of the Madagascar Ridge (for bottom topography, see Figure 1a). He has constructed maps for 2-calendar-month periods, in this way reducing the number of data available for each portrayal. A number of other circulation cells, of small dimensions, are also evident in Wyrtki's [1971] maps, but most are seen in only one 2-month period and are therefore probably artifacts of the data distribution. It is perhaps of passing interest to note 

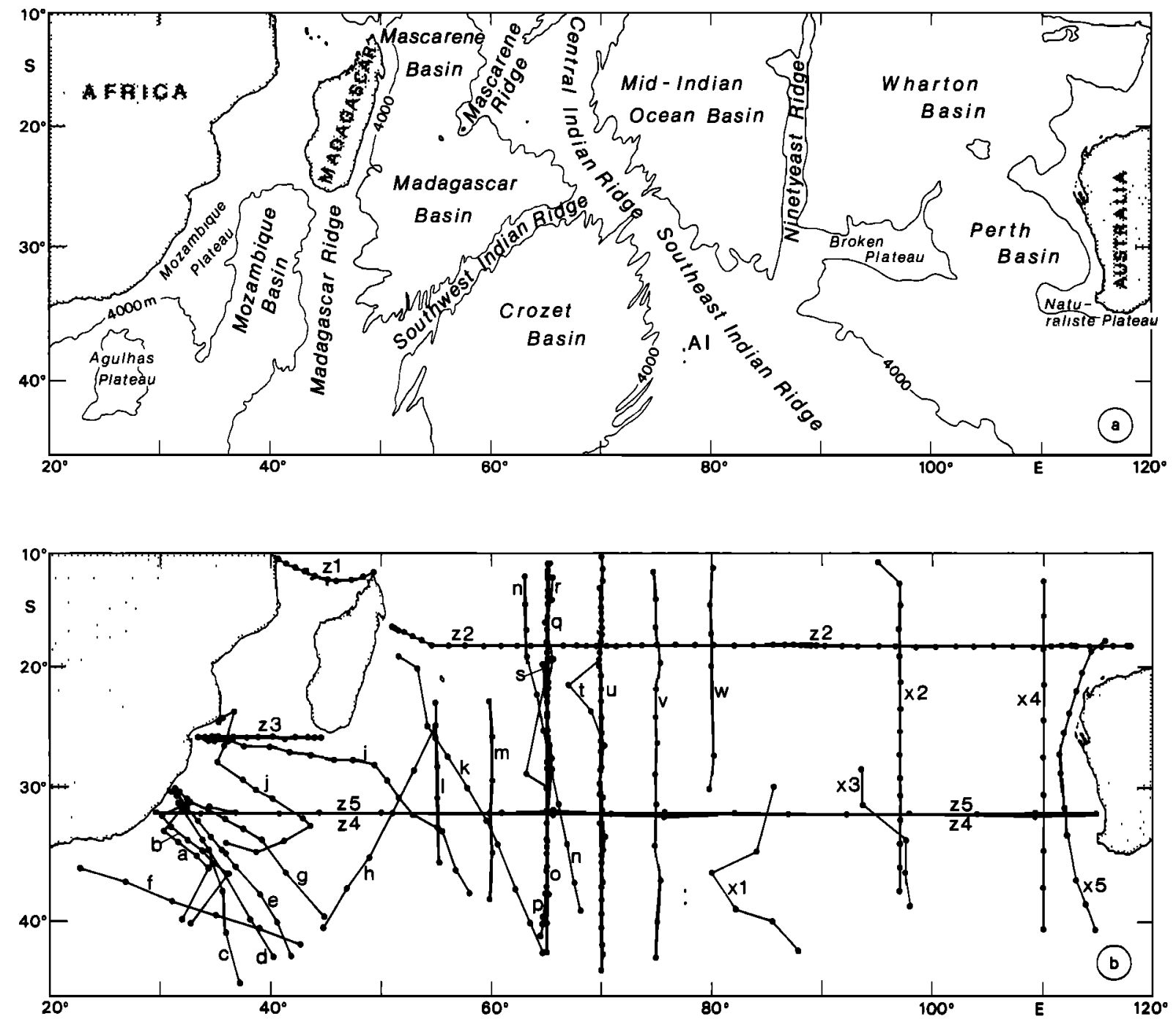

Figure 1. The South Indian Ocean with (a) the main features of the bottom topography represented by the smoothed 4000-m isobath (AI indicates the Amsterdam Island) and (b) the sections (lines) as listed in Table 1 and positions (dots) of hydrographic data used for this investigation.

that marine biologists [Heydorn et al., 1978] have hypothesized three main circulations in the South Indian in order to accomodate the movement of e.g., turtle species in this ocean. One is the full width of the South Indian with a circulation rate of years, one is a southwest Indian Ocean subgyre and the last is an intermediate one somewhere in between.

From the atlas plates by Wyrtk [1971] it is clear that the circulation of the basin has a distinct pivot in the southwestern corner, i.e., in the Agulhas Basin. This has subsequently been confirmed by the work of Harris [1972] and Lutjeharms [1976] (Figure 2a). The depth of the $10^{\circ} \mathrm{C}$ isotherm in this southwest Indian Ocean subgyre is about $850 \mathrm{~m}$, compared to $600 \mathrm{~m}$ for the analogous location in the South Atlantic gyre [Wüst, 1978], suggesting the comparatively increased intensity of the circulation about this point in the South Indian Ocean.
The data used in the above studies of the large-scale gyral circulation [Wyrtki, 1971; Harris, 1972; Lutjeharms, 1976] have considerable overlap so that these results cannot be considered to be entirely independent. Furthermore, the existence of intense anticyclonic eddies in the center of the southwest Indian subgyre [Gründlingh, 1989; Gründlingh et al., 1991] creates a biasing problem in the data. If such an eddy were sampled once in the widely spaced data of the historical database, but not spatially resolved, it might have lead to the portrayal of a falsely intensified subgyre recirculation.

The existence of well-developed subgyres within the general basin-wide gyre of the South Indian circulation has a number of wider implications. One of these concerns the sources of the Agulhas Current. Early portrayals of the currents that feed the Agulhas Current are based for the greater part on measurements of ships' 

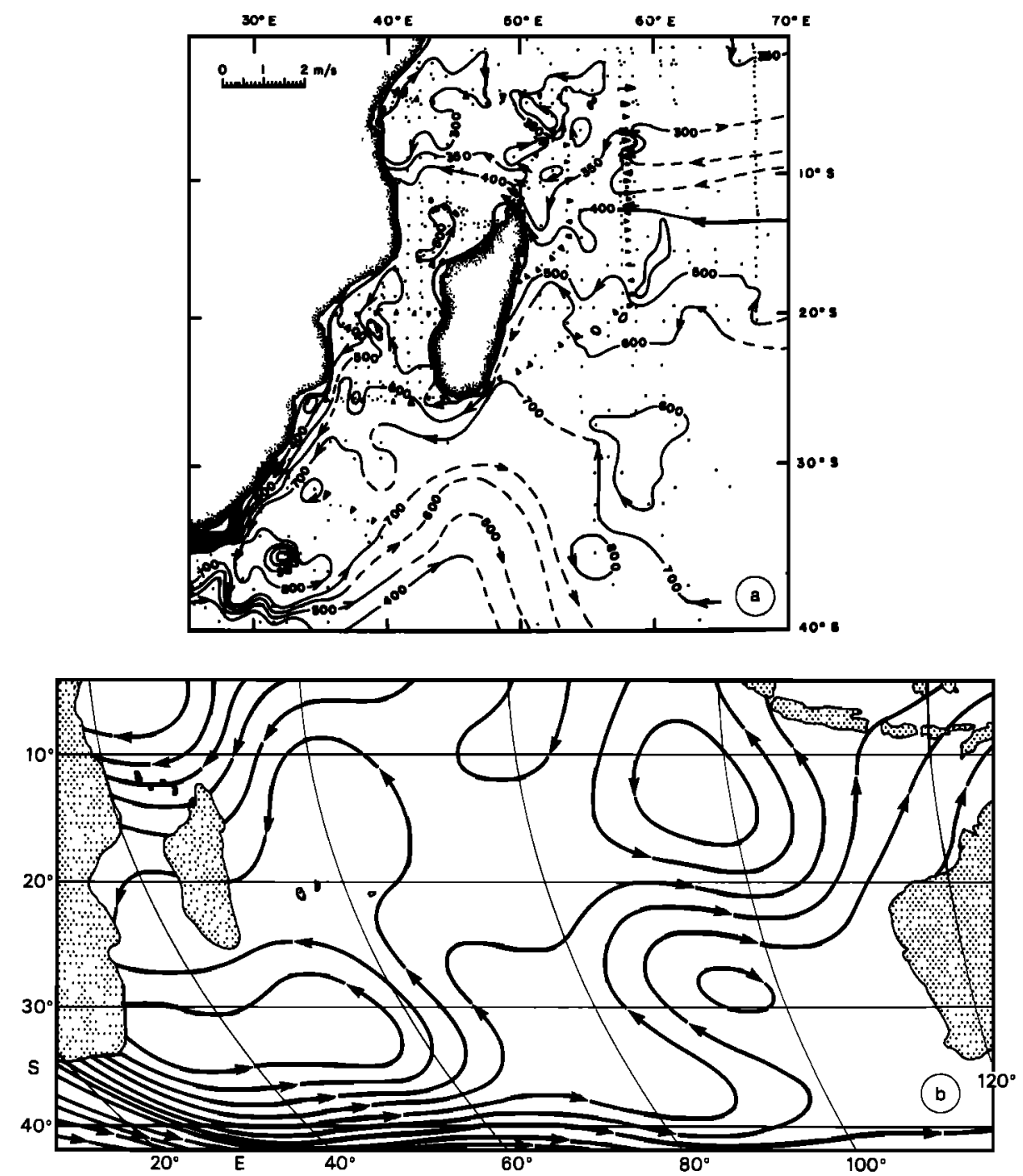

Figure 2. (a) The anticyclonic subgyre of the South Indian circulation in the Agulhas Basin relative to the depth of the $\sigma_{\Theta}=26.8$ surface during the northeast monsoon season [after Lutjeharms, 1976]. (b) The circulation of the South Indian subtropical gyre extracted from a map of global ocean dynamic topography based on sea surface height measurements from the TOPEX/POSEIDON for October 19923 to 12, [after Fu and Christensen, 1993].

drift and in some cases sea surface temperatures [e.g., Möller, 1929; Paech, 1926; Michaelis, 1923]. They show a simple and direct inflow into the northern Agulhas Current from the South Equatorial Current, one via the Mozambique Channel, called the Mozambique Current, the other around the southern tip of Madagascar, called the East Madagascar Current. The concept of the Mozambique Current as an upstream extension of the Agulhas Current seems to be wrong [Saetre and Jorge da Silva, 1984], the circulation in the channel in fact consisting of a series of recirculation cells instead. Furthermore, the surface connection between the East Madagascar Current and the Agulhas Current does not exist either, except perhaps in a sporadic way by filaments and eddies [Lutjeharms et al., 1981; Lutjeharms, 1988].

If these two sources are not as important as previously thought, the water of the Agulhas Current must come from a large measure of recirculation, thus allowing the concept of a strongly developed recirculation cell in the gyral circulation of the South Indian Ocean to gain additional importance. A rough estimate of the volume contributions to the Agulhas Current [Harris, 1972] from hydrographic data has suggested that about $35 \mathrm{~Sv}(1$ Sverdrup $=10^{6} \mathrm{~m}^{3} \mathrm{~s}^{-1}$ ) comes from east of Madagascar (not necessarily via the East Madagascar Current), 10 Sv only comes through the Mozambique Channel, and $27 \mathrm{~Sv}$ is recycled in a southwest Indian Ocean subgyre. $F u$ [1986], using an inverse method solution for six hydrographic sections in the Indian Ocean, has indicated a southward transport of only $6 \mathrm{~Sv}$ through the Mozambique Channel. Gordon [1986] has suggested that the water mass composition of the Agulhas Current indicates that the water on the inshore edge of the current does originate in the Mozambique Channel. The large degree 
of variability in the throughflow [Lutjeharms, 1972] suggests why these estimates may vary considerably.

The recirculation of the subtropical gyre of the South Indian Ocean seems to take place in the western and central parts of the subtropical gyre. TOPEX/POSEIDON altimeter data for the period October 3 to 12 , 1992 [Fu and Christensen, 1993] (Figure 2b), show two recirculation paths, one at about $65^{\circ} \mathrm{E}$ flowing back to the Agulhas Current mainly south of Madagascar, while another band moved northward at about $95^{\circ} \mathrm{E}$, while no major flow was indicated southwest of Australia. ERS 1 data for the period November 1992 to March 1993 [Naeije et al., 1994] show almost complete recirculation west of about $90^{\circ} \mathrm{E}$ with only minor northward flow indicated just off the western Australian coast. In this case the return flow seemed to move westward mainly east of Madagascar. Although the geostrophic computations [Stramma, 1992] as well as the altimeter data indicate a major recirculation of the South Indian Ocean Current (SIOC) in the western and central part of the South Indian Ocean, it is not yet clear where the westward flow takes place and how it contributes to the Agulhas Current.

It therefore seems clear that despite the information on the SIOC [Stramma, 1992] neither the inflow to the Agulhas Current, the dimensions and transport of a South West Indian Ocean subgyre, the flow patterns of a western recirculation cell of intermediate size in the South Indian subtropical gyre, nor the total gyre circulation are well understood. Using historical hydrographic sections and water characteristics we attempt here to derive the mean flow field of the South Indian Ocean and compare it with results in the literature.

\section{Methods}

Several quasi-synoptic hydrographic sections in the subtropical gyre of the South Indian Ocean have been extracted from a digitized database supplied by the World Oceanographic Data Center (WDC-A) in Washington, D.C. In the open ocean, all identifiable continous sections were used, while near the coast, some sections selected for closer station spacing were used. Some basic details concerning the sections are provided in Table 1 and the geographic distribution is shown in Figure 1b. Meridional sections were taken south of $10^{\circ} \mathrm{S}$. As most of the sections in the southern part were used by Stramma [1992] for the investigation of the South Indian Ocean Current, the southernmost extent of the sections was selected to be just south of the SIOC location described by Stramma [1992].

As the data originate from a long period and were measured by different methods, the accuracies between sections might vary, especially for the oxygen distribution. For example, the RRS Discovery chemistry data between 1930 and 1951 are known to contain systematic errors. For the RRS Discovery oxygen data, Gordon and Molinelli [1986, p. 8] introduced a correction factor of
0.4 to $0.6 \mathrm{~mL} / \mathrm{L}$. We corrected the zonal RRS Discovery oxygen section at $32^{\circ} \mathrm{S}$ by an offset of $0.5 \mathrm{~mL} / \mathrm{L}$. This oxygen section is useful to show the minimum and maximum that represent the water mass distribution, but a direct comparison to the other sections would suffer from the different accuracies of the measurements. This investigation combines some hydrographic sections currently available (which have been used in the literature for local investigations) and combines the results to produce one schematic flow field. It does not present any new sections.

Most of the water from the Agulhas Current retroflects south of South Africa as the Agulhas Return Current and moves to the east near $40^{\circ} \mathrm{S}$ at the Subtropical Front (also referred to as Subtropical Convergence) to become the South Indian Ocean Current [Lutjeharms and Van Ballegooyen, 1984]. Stramma [1992] has investigated the movement of the SIOC across the southern Indian Ocean using historical hydrographic data. Near Africa he estimated a typical volume transport of $60 \mathrm{~Sv}$ in the upper $1000 \mathrm{~m}$. Along the movement to the east the SIOC recirculated about $20 \mathrm{~Sv}$ at about $50^{\circ} \mathrm{E}$ which seemed eventually to flow back into the Agulhas Current. Another $20 \mathrm{~Sv}$ recirculated between $60^{\circ}$ and $70^{\circ} \mathrm{E}$, while the remaining $20 \mathrm{~Sv}$ was split up into $10 \mathrm{~Sv}$ turning northward just east of $90^{\circ} \mathrm{E}$ and $10 \mathrm{~Sv}$ flowing northward several hundred kilometers west of Australia [Stramma, 1992]. No further information on recirculation paths was given.

For geostrophic computations, a variable reference depth based on water mass properties is assumed. Therefore some information on the water masses is presented first. The surface layer of the southwest Indian Ocean is dominated by high-salinity Subtropical Surface Water. In the northern part, there is low-salinity Tropical Surface Water that propagates southward. Superposition of the two water masses causes a subsurface salinity maximum at $150-200 \mathrm{~m}$.

For the subsurface water masses in the Indian Ocean we follow the nomenclature of Toole and Warren [1993]. The water below the surface layer was originally called Indian Ocean Central Water by Sverdrup et al. [1942], and in recent observations [e.g., Frne, 1993; Toole and Warren, 1993] it is refered to as Subantarctic Mode Water (SAMW) following the investigation of McCartney [1977, 1982] and a review of the names by Warren [1981b]. SAMW is formed during winter cooling by deep convective overturning in the zone between the Subtropical Front and the Subantarctic Front and appears in summer sections as pycnostads beneath the seasonal thermocline. Associated with this pycnostad is a subsurface oxygen maximum centered at $300-500 \mathrm{~m}$, which is used as indicator of Mode Water. For the South Indian Ocean, McCartney [1982] has centered the formation region for a lighter type of SAMW $\left(\sigma_{\Theta}=26.7\right)$ at about $70^{\circ} \mathrm{E}$ and for a heavier type $\left(\sigma_{\odot}=26.85\right)$ in the eastern South Indian Ocean. Park et al. [1993] have described similar findings to that of Toole and Warren 
Table 1. Meridional and Zonal Sections Appearing in Figure $1 \mathrm{~b}$ as Well as 0- to 1000-m Transports for the Major Current Bands

\begin{tabular}{|c|c|c|c|c|}
\hline Ship & Longitude & Time & Currents & Volume Transport, Sv \\
\hline $\begin{array}{c}\text { (a) Natal } \\
\text { (b) Natal } \\
\text { (c) Discovery } \\
\text { (d) Discovery } \\
\text { (e) Robert D. Conrad } \\
\text { (f) Discovery } \\
\text { (g) Natal } \\
\text { (h) Fuji } \\
\text { (i) Africana } \\
\text { (j) Anton Bruun } \\
\text { (k) Unknown* } \\
\text { (l) Anton Bruun } \\
\text { (m) Anton Bruun } \\
\text { (n) Ob } \\
\text { (o) Akademik Korolev } \\
\text { (p) Anton Bruun } \\
\text { (q) Yu. M. Schokalsky } \\
\text { (r) Yu. M. Schokalsky } \\
\text { (s) A.I. Voeikov } \\
\text { (t) Anton Bruun } \\
\text { (u) Akademik Shirshov } \\
\text { (v) Anton Bruun } \\
\text { (w) Anton Bruun } \\
\text { (x1) Eltanin } \\
\text { (x2) Ob } \\
\text { (x3) Eltanin } \\
\text { (x4) Gascoyne } \\
\text { (x5) A. I. Voetkov }\end{array}$ & $\begin{array}{l}30^{\circ}-34^{\circ} \mathrm{E} \\
30^{\circ}-36^{\circ} \mathrm{E} \\
32^{\circ}-37^{\circ} \mathrm{E} \\
31^{\circ}-40^{\circ} \mathrm{E} \\
31^{\circ}-41^{\circ} \mathrm{E} \\
22^{\circ}-42^{\circ} \mathrm{E} \\
31^{\circ}-44^{\circ} \mathrm{E} \\
44^{\circ}-54^{\circ} \mathrm{E} \\
33^{\circ}-58^{\circ} \mathrm{E} \\
35^{\circ}-43^{\circ} \mathrm{E} \\
51^{\circ}-64^{\circ} \mathrm{E} \\
55^{\circ} \mathrm{E} \\
60^{\circ} \mathrm{E} \\
62^{\circ}-68^{\circ} \mathrm{E} \\
65^{\circ} \mathrm{E} \\
65^{\circ} \mathrm{E} \\
65^{\circ} \mathrm{E} \\
65^{\circ} \mathrm{E} \\
65^{\circ} \mathrm{E} \\
70^{\circ} \mathrm{E} \\
70^{\circ} \mathrm{E} \\
75^{\circ} \mathrm{E} \\
80^{\circ} \mathrm{E} \\
80^{\circ}-87^{\circ} \mathrm{E} \\
94^{\circ}-97^{\circ} \mathrm{E} \\
93^{\circ}-98^{\circ} \mathrm{E} \\
110^{\circ} \mathrm{E} \\
111^{\circ}-115^{\circ} \mathrm{E}\end{array}$ & $\begin{array}{l}\text { Aug. } 1962 \\
\text { Oct. } 1962 \\
\text { April } 1935 \\
\text { May } 1935 \\
\text { April } 1974 \\
\text { Nov. } 1935 \\
\text { July } 1962 \\
\text { March } 1977 \\
\text { June } 1961 \\
\text { Aug. } 1964 \\
\text { Jan. } 1956 \\
\text { March } 1964 \\
\\
\text { Sept. } 1963 \\
\text { May } 1956 \\
\text { March } 1973 \\
\text { June } 1964 \\
\text { Jan. } 1970 \\
\text { June } 1970 \\
\text { Jan. } 1969 \\
\\
\text { June } 1963 \\
\text { Nov. } 1970 \\
\text { April } 1964 \\
\text { July } 1963 \\
\text { July } 1971 \\
\text { April } 1957 \\
\text { July } 1971 \\
\text { Sept. } 1962 \\
\text { Nov. } 1970\end{array}$ & $\begin{array}{c}\text { AC } 60.5 \\
\text { AC } 33.2 \\
\\
\text { AC } 68.1 \\
\text { AC } 60.4 \\
\\
\\
\text { AC } 32.4 \\
\text { AC } 34.1 \\
\text { EMC } 14.3 \\
\text { central part } \\
\text { of gyre } \\
\\
\text { NSEC } 12.4 \\
\text { NSEC } 9.8 \\
\text { NSEC } 11.7 \\
\text { NSEC } 11.2 \\
\text { NSEC } 8.0 \\
\text { central part } \\
\text { of gyre } \\
\text { NSEC } 15.5 \\
\text { NSEC } 13.3 \\
\text { NSEC } 29.2 \\
\text { NSEC } 4.0 \\
\text { SEC } 13.6 \\
\text { WAC } 11.7 \\
\text { WAC } 4.7\end{array}$ & $\begin{array}{l}\text { SIOC } 32.6^{+} \\
\text {SIOC } 65.7 \\
\text { SIOC } 61.3 \\
\text { SIOC } 65.3 \\
\text { SIOC } 67.5 \\
\text { SIOC } 56.8 \\
\text { SIOC } 60.8 \\
\text { SIOC } 58.7 \\
\text { SIOC } 27.4\end{array}$ \\
\hline Ship & Latitude & Time & Currents & Volume Transport, Sv \\
\hline $\begin{array}{l}\text { (z1) Atlantis } \\
\text { (z2) Atlantis } \\
\text { (z3) Atlantis } \\
\text { (z4) Atlantis } \\
\text { (z5) Discovery }\end{array}$ & $\begin{array}{c}10^{\circ}-13^{\circ} \mathrm{S} \\
16^{\circ}-18^{\circ} \mathrm{S} \\
26^{\circ} \mathrm{S} \\
32^{\circ} \mathrm{S} \\
32^{\circ} \mathrm{S}\end{array}$ & $\begin{array}{l}\text { Oct. } 1963 \\
\text { July } 1976 \\
\text { June } 1965 \\
\\
\text { July } 1965 \\
\text { April } 1936\end{array}$ & $\begin{array}{l}\text { different } \\
\text { cells } \\
\text { several } \\
\text { bands } \\
\text { several } \\
\text { cells } \\
\text { AC } 4.5^{+} \\
\text {AC } 42.6\end{array}$ & $\begin{array}{l}\text { WAC } 9.9 \\
\text { WAC } 16.7\end{array}$ \\
\hline
\end{tabular}

AC, Agulhas Current; SIOC, South Indian Ocean Current; EMC, East Madagascar Current; NSEC, northern part of South Equatorial Current (typically north of $15^{\circ} \mathrm{S}$ on the western side); WAC, West Australian Current.

"According to one reviewer the ship was called Laperouse.

+Only part of the currents measured by the section.

[1993] for the Crozet Basin, namely that colder, fresher, oxygen-richer, and denser Mode Water varieties develop in the eastern South Indian Ocean and have suggested that the lighter Mode Water in the Crozet Basin is locally produced.

Below the Subantarctic Mode Water the Antarctic Intermediate Water (AAIW), indicated by a salinity min- imum at about 1000-m depth, spreads northward to about $10^{\circ} \mathrm{S}$. Clowes [1950] and Harris [1972] have found an intensified circulation of intermediate water in the western South Indian Ocean. More recently, this intensification has been estimated and discussed by Toole and Warren [1993], Schmitz [1995], and Robbıns and Toole [1996]. In the South Indian Ocean, anticyclonic flow of 
AAIW has been deduced by Wyrtki [1973]. He has also pointed out that the flow is intensified in the western part of the basin. Observations by Park and Gamberoni [1996] indicate that the injection of AAIW into the subtropical gyre occurs in intermittent and pulsed events. Below the AAIW an oxygen minimum is found, which Wyrtki [1971] has shown to be at the density $\sigma_{\odot}=$ 27.6 between $30^{\circ}$ and $50^{\circ} \mathrm{S}$. Often this oxygen minimum is regarded an an isolated extremum caused by the local consumption in a region of weak flow [e.g., Toole and Warren, 1993] and is called here the oxygen minimum layer, while sometimes the oxygen minimum is attributed to the upper Circumpolar Deep Water [e.g., Park et al., 1993]. Toole and Warren [1993] have stated that the meridional oxygen gradients suggest the influence from the north for the extreme core values at the western side, while the more moderate oxygen minimum in the range $40^{\circ}$ to $70^{\circ} \mathrm{E}$ at $32^{\circ} \mathrm{S}$ implies southward influence. Hence the layer of the oxygen minimum still shows a weak signature of the subtropical gyre.

The Circumpolar Deep Water is prominently characterized in the Indian Ocean by high silica located underneath the deep oxygen minimum layer, sometimes called Atlantic-Indian Deep Water, Common Water, or Indian Deep Water [Tomczak and Godfrey, 1994]. In the subtropical South Indian Ocean the inflowing Circumpolar Deep Water from the south is characterized by the high salinity, high oxygen, and low nutrient concentrations typical of Circumpolar Deep Water [Toole and Warren, 1993; Mantyla and Rerd, 1995]. In the southwestern Indian Ocean the Circumpolar Deep Water shows a salinity maximum at about $2500 \mathrm{~m}$, and this is clearly due to infusion of North Atlantic Deep Water being carried eastward [Warren, 1981a]. The northward flow of Circumpolar Deep Water in the subtropical South Indian Ocean occurs primarily in three systems of deep western boundary currents guided by the topography and no longer reflects the influence of the subtropical gyre.

For an investigation of the SIOC, Stramma [1992] has selected a reference layer for the geostrophic computations that lies underneath the Circumpolar Deep Water and above the Antarctic Bottom Water. The chosen density was $\sigma_{4}=45.87$ and is located in the depth range of $2800-3500 \mathrm{~m}$. For sections not reaching this depth a density surface $\sigma_{2}=36.94$ (depth range 1500$2500 \mathrm{~m}$ ), located between the oxygen minimum layer above and the Circumpolar Deep Water underneath, was chosen.

The depth of the density surface $\sigma_{2}=36.94$ can be seen in Figure 3 for the salinity and oxygen distribution of the section (i; Figure 1b) of RV Africana running from the African coast at $25^{\circ} 55^{\prime} \mathrm{S}, 33^{\circ} 33$ ' $\mathrm{E}$ first to the east to $28^{\circ} 11^{\prime} \mathrm{S}, 49^{\circ} 11^{\prime} \mathrm{E}$ and then to the southeast to $37^{\circ} 56^{\prime} \mathrm{S}$, $58^{\circ} 03^{\prime} \mathrm{E}$. Two other sections, one meridional section at $110^{\circ} \mathrm{E}$ of RV Gascoyne between $12^{\circ} 30^{\prime} \mathrm{S}$ and $40^{\circ} 24^{\prime} \mathrm{S}$ (Figure 4) and one zonal section at $32^{\circ} \mathrm{S}$ of RRS Discovery between $29^{\circ} 48^{\prime} \mathrm{E}$ and $114^{\circ} 52^{\prime} \mathrm{E}$ (Figure 5), show the distribution of salinity and oxygen and include the density surface $\sigma_{2}=36.94$. The density surface $\sigma_{2}=$ 36.94 is clearly located between the salinity minimum of the AAIW and the salinity maximum of the Circumpolar Deep Water (Figures 3a, 4a, and 5a) and well below the oxygen minimum layer (Figures $3 \mathrm{~b}, 4 \mathrm{~b}$, and $5 \mathrm{~b}$ ) located above the Circumpolar Deep Water. As given by Toole and Warren [1993], the deep oxygen minimum at about $1500 \mathrm{~m}$ is developed most prominently in the eastern third of the $32^{\circ} \mathrm{S}$ section (Figure $5 \mathrm{~b}$ ).

Toole and Warren [1993] have carried out geostrophic calculations for a zonal section at $32^{\circ} \mathrm{S}$. To investigate also the flow of Circumpolar Deep Water, they made a careful choice of the reference depth for each ocean basin based on the water property distribution and spreading direction. Except for some special regions, the reference depth was in most cases located near 2000 dbar. Robbins and Toole [1996] have recalculated the section used by Toole and Warren [1993] for density layers with the inclusion of the advective flux of dissolved silica. This has led to locally varying barotropic velocity adjustments of a few centimeters; their density surface separating southward from northward flow was located slightly below $2000 \mathrm{~m}$. At a zonal section at $18^{\circ} \mathrm{S}$, Warren [1981b] has found that the upper ocean flow did not change much as long as a reference depth between 1000 and $2000 \mathrm{~m}$ was chosen. Therefore a reference depth near $2000 \mathrm{~m}$ seems to have no larger impact on the transport field for the upper ocean of the subtropical gyre, while transport fields for the Circumpolar Deep Water, as investigated by Toole and Warren [1993], will be more strongly influenced by the choice of the reference surface. For our investigation we use the density $\sigma_{4}=45.87$ as reference surface just within the SIOC at the southern boundary, while north of the SIOC the density $\sigma_{2}=36.94$ was used as reference layer for the geostrophic computations. As was noted in the water mass description, this surface is located between the deep oxygen minimum layer still influenced by the subtropical gyre and the Circumpolar Deep Water flowing along the bottom topography. For station pairs not reaching the required depth of the density surface the deepest common depth was used as the integration reference.

\section{Observations}

The two sections of Figures 3 and 4 represent the distribution of hydrographic variables in the west and in the east of the South Indian Ocean, while Figure 5 represents the zonal distribution along $32^{\circ} \mathrm{S}$. Since the temperature distributions are not particularly informative, only salinity and oxygen for the entire depth range and the geostrophic velocity for the upper $1000 \mathrm{~m}$ are presented. In addition, for the discussion of the SAMW and the derived flow field, the depth of the isopycnal $\sigma_{\Theta}=26.7$, the salinity distribution on this density surface, and the salinity distribution at 400-m depth from the sections used here are shown in Figure 6. 

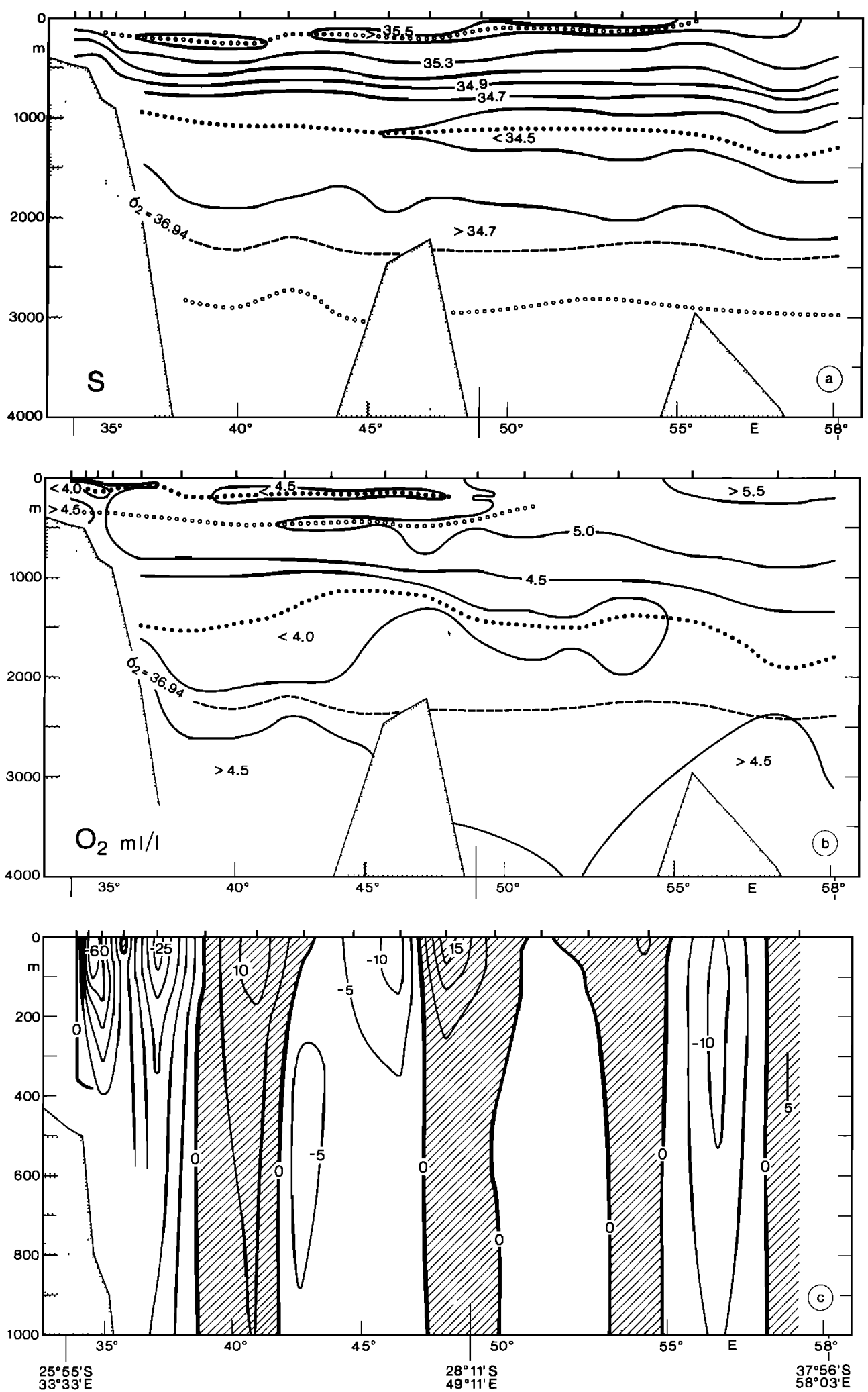

Figure 3. Vertical distribution of (a) salinity, (b) oxygen in milliliters per liter, and (c) southward or southwestward geostrophic speed in centimeters per second (northward or northeastward speed is shaded) relative to the potential density surface $\sigma_{2}=36.94$ along the line of stations occupied by RV Africana (section i in Figure 1b) at $33^{\circ}$ to $58^{\circ} \mathrm{E}$. Velocities larger than $25 \mathrm{~cm} \mathrm{~s}^{-1}$ in the upper $100 \mathrm{~m}$ west of $35^{\circ} \mathrm{E}$ are only shown by the maximum velocity. Relative maxima are denoted by open circles, and minima are denoted by solid circles. Also shown is the isopycnal $\sigma_{2}=36.94$ (broken line). 

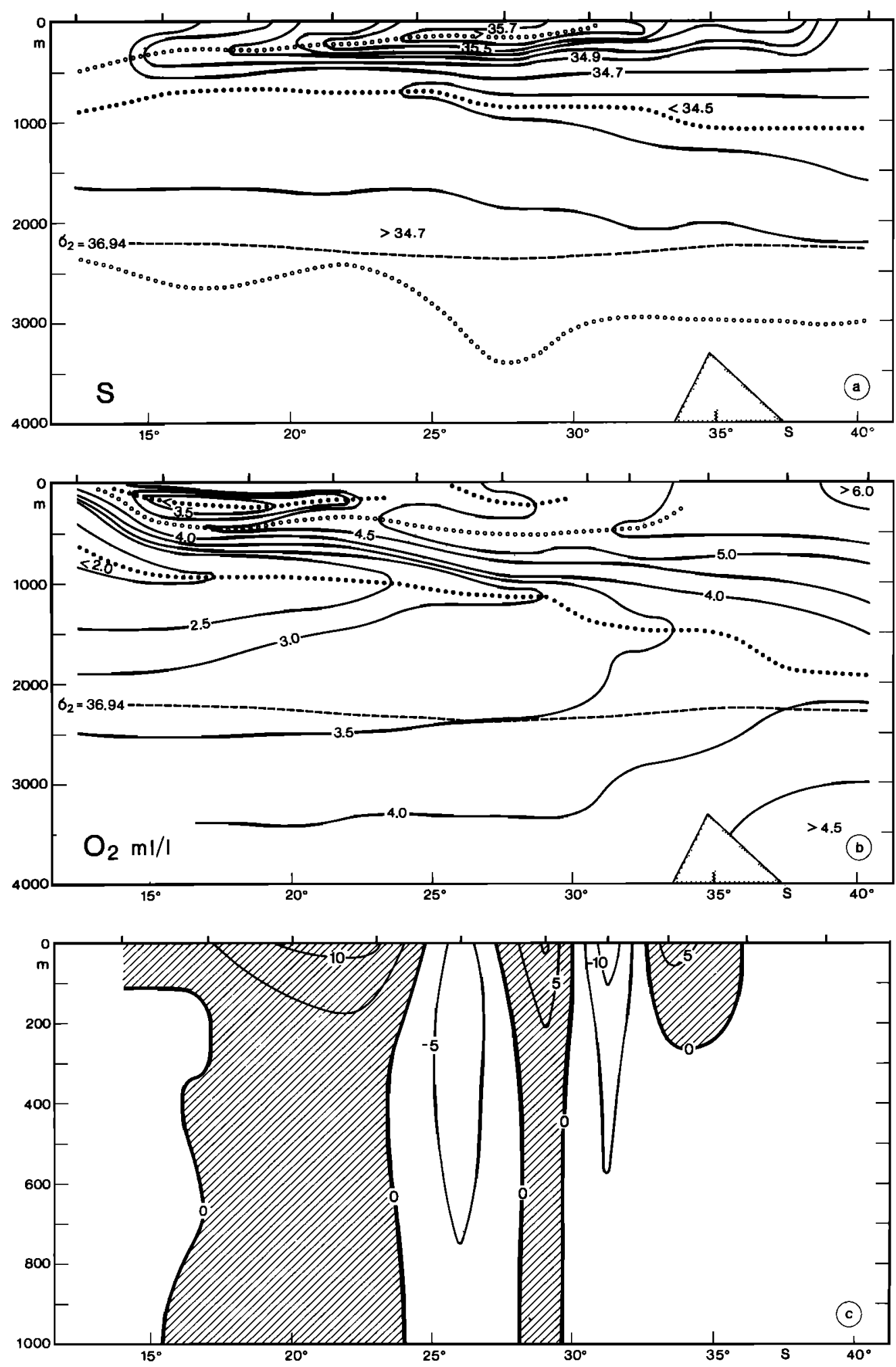

Figure 4. As in Figure 3, but for the line of stations occupied by RV Gascoyne (section $\mathrm{x} 4$ in Figure 1b) at $110^{\circ} \mathrm{E}$. Eastward speed in Figure $4 \mathrm{c}$ is shaded.

\subsection{Distribution of Hydrographic Variables}

The surface salinity at the southern end of the RV Africana section (Figure $3 \mathrm{a}$ ), with a value of 35.4 , indicates that the section is well north of the Subtropical
Front (STF) with salinities of about 34.8. The STF west of $100^{\circ} \mathrm{E}$ often is connected to the SIOC [Stramma, 1992]. The strong salinity minimum of the AAIW in the south reaches northwestward to a location south of Madagascar, while the minimum layer is weak between 

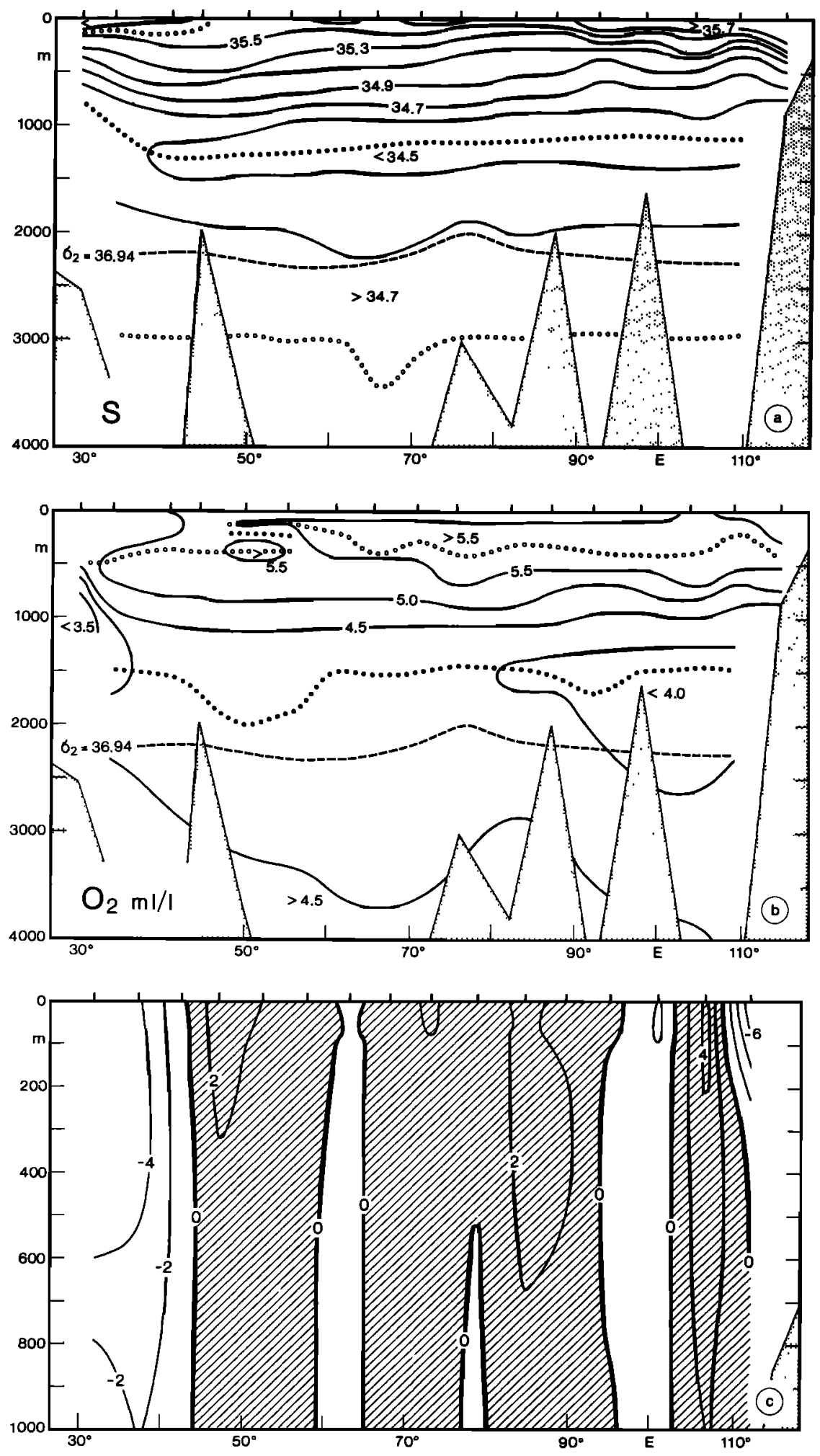

Figure 5. As in Figure 3, but for the line of stations occupied by RRS Discovery (section $\mathrm{z} 5$ in Figure $1 \mathrm{~b}$ ) at $32^{\circ} \mathrm{S}$. The oxygen distribution in Figure $5 \mathrm{~b}$ was corrected upward by $0.5 \mathrm{~mL} / \mathrm{L}$. Northward speed in Figure 5c is shaded.

the African continent and south of Madagascar. The accompanying oxygen minimum (Figure $3 \mathrm{~b}$ ) shows a weak mimimum in the south, while the oxygen minimum is strong in the region between Africa and Madagascar.
The meridional section in the east, at $110^{\circ} \mathrm{E}$, was actually made by RV Gascoyne between $12^{\circ} 30^{\prime}$ and $30^{\circ} 30^{\prime} \mathrm{S}$ and by RV Diamantina to the south, but as these cruises were only 10 days apart, we have combined 

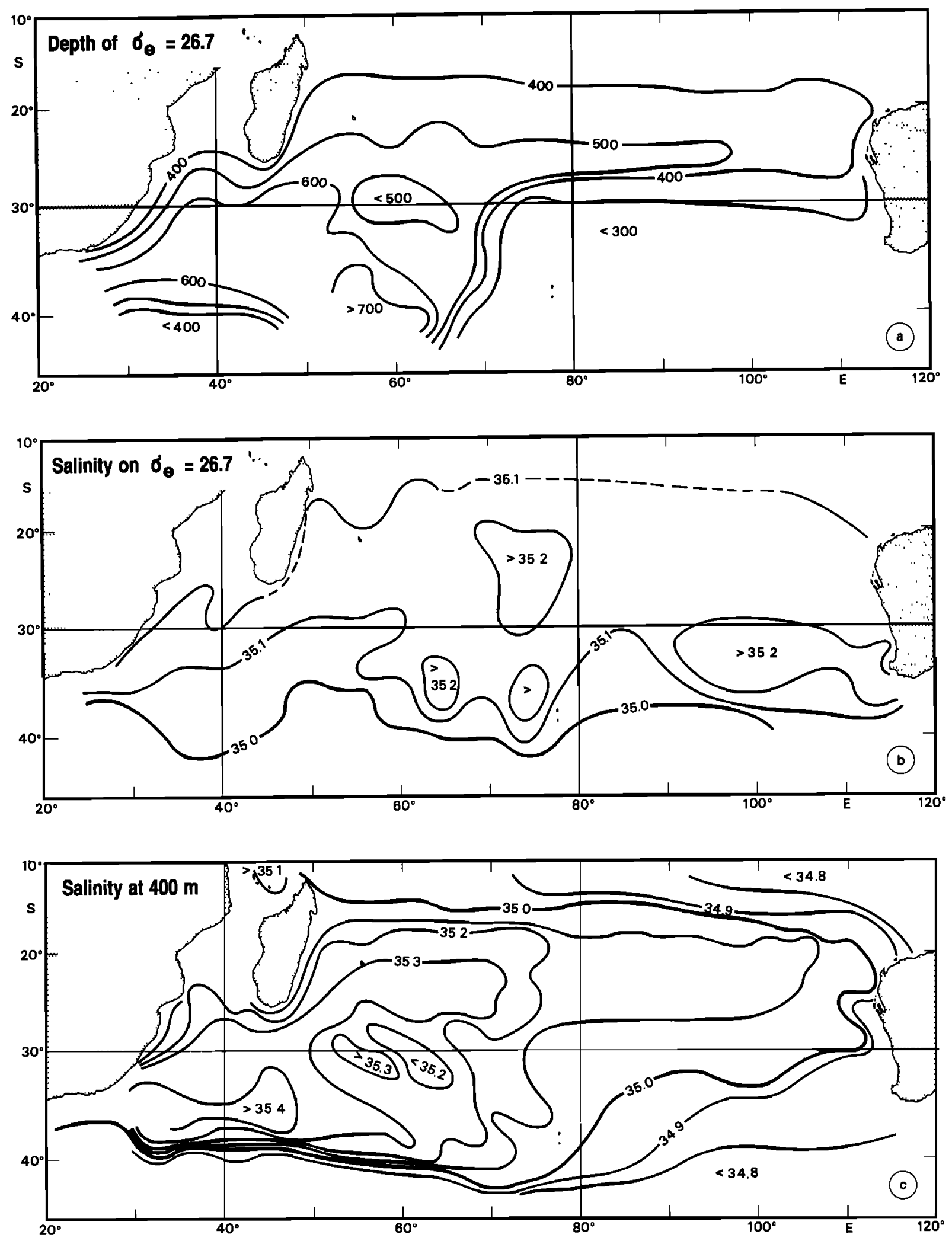

Figure 6. Distribution of (a) the depth of the isopycnal surface $\sigma_{\Theta}=26.7$, (b) the salinity on the isopycnal surface $\sigma_{\Theta}=26.7$, and (c) the salinity distribution at $400-\mathrm{m}$ depth from the sections used here. 
them to form one section and call section $\mathrm{x} 4$ (Figure $1 \mathrm{~b}$ ) simply the RV Gascoyne section. The STF is reflected in the strong salinity gradient at the southernmost station pair. At $110^{\circ} \mathrm{E}$ the salinity minimum of the AAIW (Figure $4 \mathrm{a}$ ) is about $200 \mathrm{~m}$ shallower than to the west in the RV Africana section. A strong subtropical salinity maximum appears at about $30^{\circ} \mathrm{S}$ at $110^{\circ} \mathrm{E}$, which is carried north at $200-$ to $400-\mathrm{m}$ depth to $15^{\circ} \mathrm{S}$. Just underneath this salinity maximum an oxygen maximum is located (Figure 4b).

The zonal salinity distribution along $32^{\circ} \mathrm{S}$ by RRS Discovery (Figure 5a) shows a deepening of the salinityrich water in the upper $800 \mathrm{~m}$ west of $60^{\circ} \mathrm{E}$. In the same region the water is oxygen-poorer than east of about $60^{\circ} \mathrm{E}$ (Figure $5 \mathrm{~b}$ ). The highest near-surface oxygen values are observed at $104^{\circ} \mathrm{E}$, at the location where a northward flow of more than $4 \mathrm{~cm} \mathrm{~s}^{-1}$ is located (Figure $5 \mathrm{c}$ ), while in the southward flow to the east, off the Australian coast, the oxygen values decrease. Similar to the recent $32^{\circ} \mathrm{S}$ section from RRS Charles Darwin in 1987, presented by Toole and Warren [1993], in the RRS Discovery section, high surface salinities in excess of 35.5 are present, reflecting the excess of evaporation over precipitation which is characteristic for the subtropics. As in the case of the 1987 section, highest salinities are found on the eastern side, while the lowest surface salinities are located in the extreme west, near the African continent. West of about $45^{\circ} \mathrm{E}$, the highest salinities are subsurface.

The subsurface salinity maximum appears north of $34^{\circ} \mathrm{S}$ in the western section (Figure $3 \mathrm{a}$ ) and north of $30^{\circ} \mathrm{S}$ in the eastern section (Figure $4 \mathrm{a}$ ). The $32^{\circ} \mathrm{S}$ salinity distribution (Figure 5a) shows the subsurface salinity maximum only at the western side, in agreement with the observations of the two presented meridional sections. As argued by Warren [1981b], the surface waters around $32^{\circ} \mathrm{S}$, made salty by evaporation, are thought to be carried north by the interior circulation. Subsequent surface warming and precipitation excess in the tropics cap the high-salinity water with a warm, lower-salinity surface layer (the Tropical Surface Water), forming the salinity extremum. Vertical mixing with the Tropical Surface Water is probably responsible for the erosion of the salinity extreme values when progressing north.

The oxygen maximum at depths of $300-600 \mathrm{~m}$ corresponds to the SAMW. The lighter type of SAMW near $\sigma_{\Theta}=26.7$ is formed in the Crozet Basin and advected within the subtropical gyre. Therefore the circulation plays an important role on the property distribution. The depth distribution of the isopycnal $\sigma_{\odot}=$ 26.7 (Figure 6a) shows a similar distribution as the one at $\sigma_{\Theta}=26.6$ presented by Wyrtkı [1971] to investigate the spreading of Persian Gulf Water and Bay of Bengal Water. A strong depth gradient is present between $30^{\circ}$ and $40^{\circ} \mathrm{S}$ near $70^{\circ} \mathrm{E}$, where the density surfaces rises by up to $400 \mathrm{~m}$. As presented by $\mathrm{Mc}$ Cartney [1982], the lighter type of SAMW is found here to be formed west of $70^{\circ} \mathrm{E}$. The salinity distribution on $\sigma_{\Theta}=26.7$ (Figure $6 \mathrm{~b}$ ) shows only weak gradients in the subtropical gyre region of the South Indian Ocean, but with salinities larger than 35.2 at and east of $60^{\circ} \mathrm{E}$.

In the western section (Figure $3 \mathrm{~b}$ ), no oxygen maximum is found south of $30^{\circ} \mathrm{S}$, indicating that no SAMW is flowing to the west against the direction of the general subtropical gyre. In the eastern section (Figure 4b) the oxygen maximum is observed only north of $34^{\circ} \mathrm{S}$; this is only in the region influenced by the subtropical gyre. Near the western boundary of the $32^{\circ} \mathrm{S}$ section (Figure 5b) the SAMW intensity is greatly diminished from the interior oxygen maximum values. Here relatively old SAMW, with the signal reduced by mixing, is apparently advected south by the Agulhas Current at the westernmost station, while the reduced oxygen maximum west of $45^{\circ} \mathrm{E}$ is from the southwest Indian Ocean subgyre, as this water recirculated from the SIOC west of the Crozet Basin, which is regarded as the formation region of the lighter type of SAMW.

\subsection{The Transport Field}

The geostrophic transports for all sections shown in Figure 1b were calculated, and the mean flow field was constructed best to represent the results of all the sections. Some transport values for the major current bands are included in Table 1, but it is not possible to list all values along each section which contributed to the construction of the mean flow field of Figure 7 . As these sections were made in different years and during different seasons, the results do not fit exactly, and the presented transport field of the South Indian Ocean is only an idealized realisation. The mean schematic transport field for the upper $1000 \mathrm{~m}$ of the subtropical gyre of the South Indian Ocean is presented in Figure 7, including also the names of the major currents. Many sections show additional features of flow in opposing directions that were interpreted as eddies or features not representing the mean transport field and are therefore not included in Figure 7 . The salinity distribution at 400-m depth (Figure 6r) reflects well the structure of the derived flow field (Figure 7).

In the upper $1000 \mathrm{~m}$ the transport of the South Indian Ocean Current as continuation of the Agulhas Return Current south of Africa starts with $60 \mathrm{~Sv}$ southeast of South Africa flowing to the east. About $20 \mathrm{~Sv}$ recirculates between $40^{\circ} \mathrm{E}$ and $50^{\circ} \mathrm{E}$ and another $20 \mathrm{~Sv}$ at $60^{\circ}$ to $70^{\circ} \mathrm{E}$. At $90^{\circ} \mathrm{E}$ the remaining $20 \mathrm{~Sv}$ of the SIOC splits up into $10 \mathrm{~Sv}$ flowing north and then returning to the west, and only $10 \mathrm{~Sv}$ continues to the northeast to move northward near Australia toward the tropical Indian Ocean. Belkın and Gordon [1.996] have defined a North Subtropical Front in the Indian Ocean between $31^{\circ}$ and $38^{\circ} \mathrm{S}$, found only between $60^{\circ}$ and $110^{\circ} \mathrm{E}$. This front seems to be connected to the water from the SIOC turning northward west of $70^{\circ} \mathrm{E}$ with part of it recirculating and part of it continuing further to the east a few degrees north of the SIOC. As was shown by Stramma [1992] for the SIOC, similar to the South Atlantic and the South Pacific, the current separates from the STF 


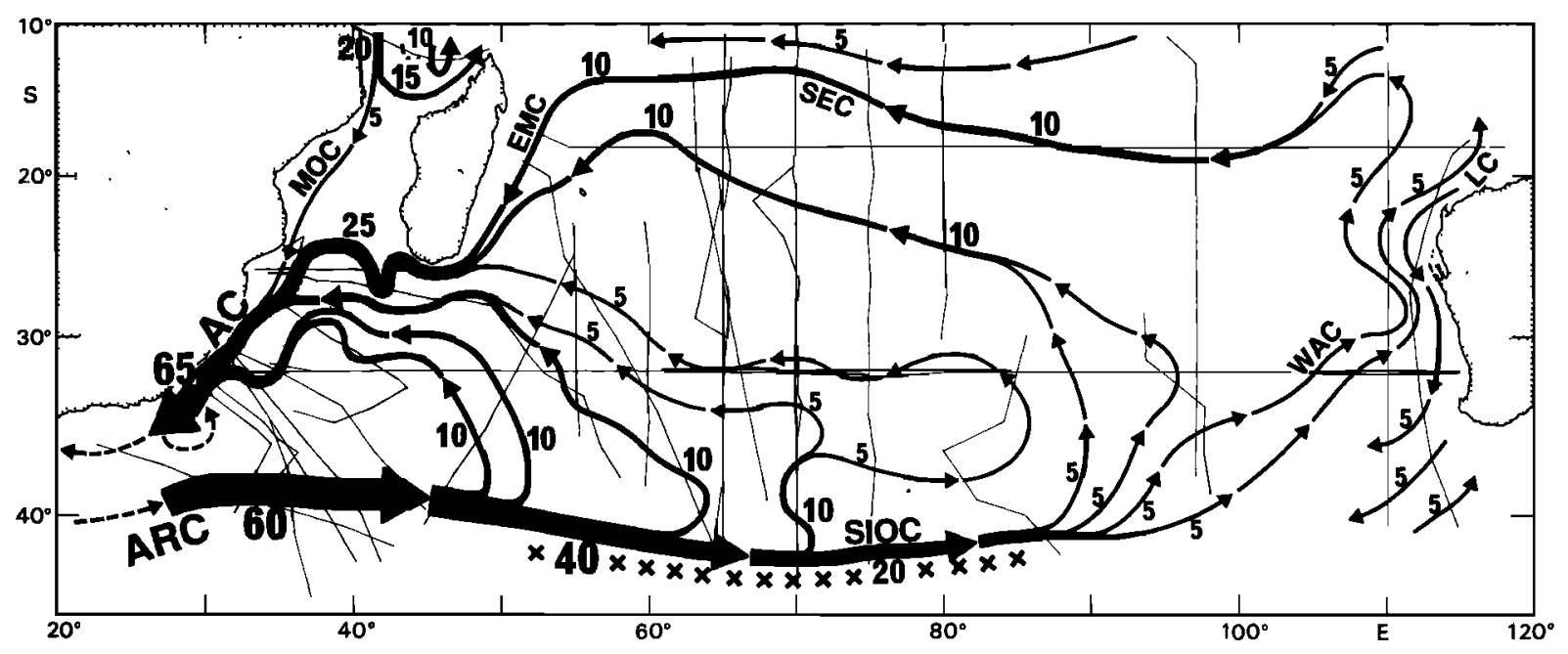

Figure 7. Schematic illustration of the flow field in the South Indian Ocean. The transports for the upper $1000 \mathrm{~m}$ in sverdrups are given by the numbers in 5-Sv steps. Thin lines indicate the sections used (see Figure 1b). The broken line near South Africa indicates a possible Agulhas recirculation cell not resolved by the sections used here. Crosses indicate the region of possible exchange between the Antarctic Circumpolar Current and the subtropical gyre. Current bands for Agulhas Return Current (ARC), South Indian Ocean Current (SIOC), West Australian Current (WAC), Leeuwin Current (LC), South Equatorial Current (SEC), East Madagascar Current (EMC), Mozambique Current (MOC), and Agulhas Current (AC) are marked.

on the eastern side of the basin, and the current turns northward while the front continues to the east; therefore on the eastern side the STF cannot be used as an indicator for the subtropical gyre flow.

Although the easternmost band of the gyre crosses the RV Gascoyne section at $110^{\circ} \mathrm{E}$ and the RV Voeikov section at about $112^{\circ} \mathrm{E}$, the RV Voeikov as well as the zonal sections at $32^{\circ} \mathrm{S}$ by RV Atlantis and RRS Discovery also show the signature of the Leeuwin Current off the western Australian coast by southward flow (Figure 5 c) with transports of up to $5 \mathrm{~Sv}$.

In the tropical region between $20^{\circ} \mathrm{S}$ and $10^{\circ} \mathrm{S}$, about $10 \mathrm{~Sv}$ flows to the west in the eastern part. Fifteen sverdrups flows to the west in the central region, but between different sections, large transport differences exist which might have a seasonal component and the given transport numbers (Figure 7) are therefore the lower bounds of the transport. Including also the return flow of $10 \mathrm{~Sv}$ originating near $90^{\circ} \mathrm{E}$ increases the South Equatorial Current (SEC) flow to $25 \mathrm{~Sv}$ in the western half of the South Indian Ocean. The flow incorporates mainly the part of the SEC returning to the south but not the transport contributed to the East African Coastal Current. Our transport of $25 \mathrm{~Sv}$ is in good agreement to model results by Woodberry et al. [1989], who have derived an annual mean westward transport for the SEC at $63^{\circ} \mathrm{E}$ between $8^{\circ}$ and $23^{\circ} \mathrm{S}$ of $24.3 \mathrm{~Sv}$. In the model results the seasonal cycle at $63^{\circ} \mathrm{E}$ turned out to be weak, the SEC transport varying only between 23.0 and $25.5 \mathrm{~Sv}$. About two thirds of the subtropical gyre recirculates within the westward flow south of $25^{\circ} \mathrm{S}$ and south of Madagascar. Only $20 \mathrm{~Sv}$ of the subtrop- ical gyre moves further north with the $10 \mathrm{~Sv}$ leaving the SIOC at about $90^{\circ} \mathrm{E}$ and flowing west at $20^{\circ}$ to $30^{\circ} \mathrm{S}$, and finally, the $10 \mathrm{~Sv}$ flows to the west through the entire Indian Ocean between $10^{\circ}$ and $20^{\circ} \mathrm{S}$.

According to the schematic flow field, about $5 \mathrm{~Sv}$ flowing through the Mozambique Channel contributes to the Agulhas Current, while $25 \mathrm{~Sv}$ comes from the east of Madagascar and $35 \mathrm{~Sv}$ recirculates south of Madagascar. From the sections used it is not entirely clear where the different flow paths merge to form Agulhas Current proper.

The continuation of the Agulhas Current seems more clear than its origin. Near $36^{\circ} \mathrm{S}$ the Agulhas Current leaves the continental shelf, develops oscillations of increasing amplitude, and usually in the region of $16^{\circ}$ to $20^{\circ} \mathrm{E}$ retroflects back toward the Indian Ocean [Lutjeharms and Van Ballegooyen, 1988] as the Agulhas Return Current (ARC) with some leakage into the South Atlantic. This water transfer from the Indian Ocean to the Atlantic varies quite considerably. From single ship sections estimates vary from $2.8 \mathrm{~Sv}$ [Bennett, 1988] and $8 \mathrm{~Sv}$ [Stramma and Peterson, 1990] to $15 \mathrm{~Sv}$ [Gordon, 1985]. A summary on the different rates found has been given by Peterson and Stramma [1991]. Recent results indicate fluxes by Agulhas rings [Van Ballegooyen et al., 1994] of $6.3 \mathrm{~Sv}$ for water warmer than $10^{\circ} \mathrm{C}$ and 7.3 Sv for water warmer than $8^{\circ} \mathrm{C}$. From a 16 -month observation of the Benguela Current, Garzoli and Gordon [1996] have estimated for the upper $1000 \mathrm{~m}$ a $13-\mathrm{Sv}$ northward transport in the Benguela Current of which $50 \%$ is from the central Atlantic, $25 \%$ comes from the Indian Ocean, and $25 \%$ may be a blend of Agulhas and 
tropical Atlantic water. According to the schematic flow field of Figure 7, about $5 \mathrm{~Sv}$ is contributed to water flow into the Atlantic, while $60 \mathrm{~Sv}$ returns east in the $\mathrm{ARC}$ and SIOC. Our leakage of $5 \mathrm{~Sv}$ from the Indian Ocean to the Atlantic Ocean is near the $4 \mathrm{~Sv}$ presented in the review of the schematic thermohaline flow field by Schmitz [1995] and the long-term observation of Garzoli and Gordon [1996].

The velocity distribution for the section (i; Figure 1b) by RV Africana (Figure 3c) shows two southward flow cores near the African shelf at about $33^{\circ} \mathrm{S}$. In this realization the highest velocity of up to $60 \mathrm{~cm} \mathrm{~s}^{-1}$ was found near the shelf. As this current band does not reach to great depth, the total transport is $8.1 \mathrm{~Sv}$ to the south, still a little larger than the $5 \mathrm{~Sv}$ indicated in the schematic flow field of Figure 7 for the Mozambique Current. Although the second southward current band reaches only surface velocities of $28 \mathrm{~cm} \mathrm{~s}^{-1}$, the transport from the surface to $1000 \mathrm{~m}$ is $24.3 \mathrm{~Sv}$ and much larger than the near-shelf current band. The southern end of this section does not reach into the SIOC. Near $35^{\circ} \mathrm{S}$, one of the recirculation cell bands is found with velocities of more than $12 \mathrm{~cm} \mathrm{~s}^{-1}$.

As the mean transport in Figure 7 is composed of all sections, no seasonal signal can be resolved. Six sections from different months between January and July were used at $65^{\circ} \mathrm{E}$, and they can possibly be used to look for a seasonal signal. The sections at $65^{\circ} \mathrm{E}$ indicate a shift in the subtropical gyre. Between January and March the southern path is located south of $30^{\circ} \mathrm{S}$, while during June/July it was located just north of $30^{\circ} \mathrm{S}$. Part of this signal was obscured by transport variability along the section, and we therefore did not try to resolve a seasonal signal.

\section{Discussion}

In this paper we have composed the transport field of the subtropical gyre of the South Indian Ocean from several hydrographic sections. A mean transport field for the upper $1000 \mathrm{~m}$ has been derived which we compare to former findings by progressing downstream in the subtropical gyre, starting in the southwest in the SIOC.

Many investigations have dealt with the Agulhas Current Retroflection south of South Africa. As this is a region of high variability, we do not attempt to reproduce the Agulhas Retroflection from only a few sections. An overview of the different findings has been given by Peterson and Stramma [1991] and by Lutjeharms [1996]. In short, south of South Africa the transport of the Agulhas Current was estimated by Gordon et al. [1987] at 95 $\mathrm{Sv}$, which is much larger than the mass flux of the Agulhas Current at about $32^{\circ} \mathrm{S}$, and Gordon et al. [1987] have therefore concluded that the Agulhas Current experiences significant enhancement within a recirculation cell indicated by a broken line in Figure 7. Usually in the region $16^{\circ}$ to $20^{\circ} \mathrm{E}$ the Agulhas Current retroflects back toward the Indian Ocean as the Agulhas Return Current. But not all of the Indian Ocean water carried into the retroflection turns back with the Agulhas Return Current, since a small portion of it leaks into the Atlantic both directly [Lutjeharms and Cooper, 1996] and through the intermittent shedding of Agulhas rings. Both exhibit high temporal variability.

The southern limit of the subtropical gyre was located here just south of the SIOC. As most of the sections used by Stramma [1992] were also used in this investigation, the transport field for the SIOC is similar to that of Stramma [1992], the SIOC starting with $60 \mathrm{~Sv}$ east of $30^{\circ} \mathrm{E}$. In the western South Indian Ocean a distinct and separate Agulhas Front [e.g., Read and Pollard, 1993] is often found north of the STF, which weakens to the east and merges with the STF in the central South Indian Ocean. Lutjeharms and Valentine [1984] have found that the retroflection of the Agulhas Current south of Africa forms this front. The Agulhas Front has a steeper density gradient than the other fronts of the Southern Ocean with a latitudinal width averaging only $100 \mathrm{~km}$. From a section at $40^{\circ} \mathrm{E}$, Read and Pollard [1993] have described an eastward, top to bottom flow of $84.2 \mathrm{~Sv}$ north of the Agulhas Front and an additional flow of $19.3 \mathrm{~Sv}$ north of the STF, much larger than our $60 \mathrm{~Sv}$ in the upper $1000 \mathrm{~m}$, but a direct comparison to our transport is probably questionable because of the different integration depths.

While the few sections available for Stramma [1992] in the Crozet Basin show a clear distinction between the SIOC and the Antarctic Circumpolar Current (ACC) to the south, data from April and May 1991 [Park et $a l ., 1993]$ result in a merging between the SIOC (which they have called Agulhas Return Current) and the ACC. Such a merging of both currents would allow an exchange of water masses, and Park et al. [1993] have in fact observed strong injection of North Indian Deep Water into the ACC south of Amsterdam Island. The different findings indicate that extreme variability in the location of the SIOC and the ACC exists in the Crozet Basin and the sea level variability from Geosat altimeter [Park et al., 1991, Figure 7] shows the largest values in this region.

Park et al. [1993] have estimated the transport of the SIOC (ARC) at the entrance to the Crozet Basin at $53^{\circ} \mathrm{E}$ as $35 \mathrm{~Sv}$, most of which recirculated northward into the northern part of the basin before reaching the Kerguelen-Amsterdam Passage at about $75^{\circ} \mathrm{E}$. The large recirculation in the western half of the South Indian Ocean might therefore be connected to the local bottom topography (Figure 1a), as about $20 \mathrm{~Sv}$ recirculates when crossing the southwest Indian Ridge just northwest of Crozet Islands, located at about $46^{\circ} \mathrm{S}$, $50^{\circ} \mathrm{E}$, and another $20 \mathrm{~Sv}$ recirculates in the Crozet Basin west of the Kerguelen-Amsterdam Passage (Kerguelen Island is located at about $49^{\circ} \mathrm{S}, 70^{\circ} \mathrm{E}$ ). The recirculation west of $70^{\circ} \mathrm{E}$ is well reflected in the eastward rise to smaller depths for the isopycnal $\sigma_{\Theta}=26.7$ (Figure 
6a), which leads to density gradients accompanied by geostrophic flow.

A test with and without bottom topography in a global ocean general circulation model [Moore and Reason, 1993] has indicated that there is increased recirculation for this region (Crozet Basin) in the case when bottom topography was included (C.J.C. Reason, personal communication, 1995) in the model. However, other physics may also contribute to the increased recirculation, and the model resolution does not allow it to capture all potentially significant topographic features. Equatorward spreading of modified thermocline water masses, i.e., Mode Water and AAIW, occurs at part of the anticyclonic circulation within the gyre and fits Fine's [1993] observation that the most recently ventilated AAIW is observed at $32^{\circ} \mathrm{S}$ west of $72^{\circ} \mathrm{E}$. The validation of the dynamic topography from TOPEX/POSEIDON even results in a complete closure of the sybtropical gyre west of $90^{\circ} \mathrm{E}$ [Park and Gamberoni, 1995], while in the geostrophic calculations (Figure 7), $10 \mathrm{~Sv}$ continues northeastward east of $100^{\circ} \mathrm{E}$.

The Leeuwin Current off western Australia has been described from the mean flow field as transporting 5 Sv southward. According to Smith et al. [1991] the Leeuwin Current is present as a poleward current most of the year between the northwest cape of Australia at $22^{\circ} \mathrm{S}$ and Cape Leeuwin at the southwestern corner of Australia, at about $35^{\circ} \mathrm{S}$. The Leeuwin Current was found between the surface and $250 \mathrm{~m}$ within $100 \mathrm{~km}$ of the shelf edge with a poleward transport of about 5 Sv by Smith et al. [1991], while Toole and Warren [1993] have estimated a flow of only 0.7 Sv. Our few sections crossing the Australian shelf region contain the signature of the Leeuwin Current, and the attributed transport of $5 \mathrm{~Sv}$ is the upper bound for this current. The Leeuwin Current is an atypical eastern boundary current flowing against the prevailing wind stress, while the so-called West Australian Current as the northward flow of the subtropical gyre is not located near the shelf but should be the northward flow of about $10 \mathrm{~Sv}$ to the west of the Leeuwin Current. Toole and Warren [1993] have observed the major northward transport at $34^{\circ} \mathrm{S}$ near $110^{\circ} \mathrm{E}$. From our few sections it is not possible to investigate how the West Australian Current and the Leeuwin Current interact. Church et al. [1989] have stated that the Leeuwin Current occurs chiefly in southern autumn and winter, while in contrast a northeastward inflow of high-salinity water, which turns to flow poleward on approaching the coast, dominates the summer situation and indicates a seasonal signal. From a water mass analysis, Tomczak and Large [1989] have shown that Australasian Mediterranean Water (originating in the basins of the Indonesian Archipelago) is carried in the Leeuwin Current as far south as $25^{\circ} \mathrm{S}$; hence the Leeuwin Current is not simply a southward return flow of the South Indian subtropical gyre.

From observations in the Tasman Sea and in the South Pacific, Stramma et al. [1995] have found that about 3
Sv of subtropical water flows southeast of Tasmania and that therefore only such a small amount of subtropical water is expected to flow from the Indian Ocean to the Pacific. In the schematic flow field of Figure 7 the 5 $\mathrm{Sv}$ of the Leeuwin Current does not return north into the South Indian subtropical gyre, and this flow might therefore contribute to a small subtropical water transfer from the Indian Ocean to the Pacific south of Australia.

Water is contributed from the Pacific to the tropical Indian Ocean within the South Equatorial Current region by the Indonesian throughflow. Warren [1981b] has described the intermediate salinity minima to be complicated by the influx of relatively fresh water from the Pacific through the Indonesian Archipelago, which produces a salinity minimum layer centered near $1000 \mathrm{~m}$. According to Warren [1981b] this water is carried westward at depths of 500 to $1200 \mathrm{~m}$ in a band approximately $10^{\circ}$ to $15^{\circ} \mathrm{S}$ by the South Equatorial Current. The westward flow below $100-\mathrm{m}$ depth in the $110^{\circ} \mathrm{E}$ section by RV Gascoyne (Figure 4) shows the southern reaches of the SEC. A possible transport of water from the Pacific is not detectable from the salinity and oxygen distribution. Toole and Warren [1993, p. 2014] have listed the large range of estimates of the Indonesian throughflow, ranging from 1 to $2 \mathrm{~Sv}$ up to $20 \mathrm{~Sv}$, which in part might be attributed to time variability, while their own analysis deduced an Indonesian throughflow transport of about $7 \mathrm{~Sv}$. A recent summary of the different existing results has been presented by Godfrey [1996]. Measurements in August 1989 [Fieux et al., 1994] have resulted in an estimate of the total transport of $18.6+/-7 \mathrm{~Sv}$ toward the Indian Ocean, but the large transport might be attributed to the time variability. Recent results from a nonlinear analytical model [Nof, 1995] suggest a throughflow of $7 \mathrm{~Sv}$. From our transport computations in the Indian Ocean a residual throughflow of 5 $\mathrm{Sv}$ is suggested, similar to the 6-year mean throughflow transport of $5 \mathrm{~Sv}$ by Meyers et al. [1995].

For the northern part of the subtropical gyre, Warren [1981b] has demonstrated a general northward component of flow in the interior of the South Indian Ocean, penetrating to the depth of the intermediate oxygen minimum at about $1000 \mathrm{~m}$. The northward volume transport was estimated geostrophically as about $20 \mathrm{~Sv}$. He has described a strong salinity maximum, a weak shallow oxygen minimum, and a somewhat stronger oxygen maximum in the longitudes $75^{\circ}$ to $100^{\circ} \mathrm{E}$, suggesting relative strong northward flow in this range. Also, our mean circulation shows the northward flow in this region but also northward flow west of $75^{\circ} \mathrm{E}$. Between $60^{\circ}$ and $100^{\circ} \mathrm{E}$ the northward flow across $18^{\circ} \mathrm{S}$ amounts to $20 \mathrm{~Sv}$. Quadfasel and Swallow [1986, p. 1307] have shown the tracks of two satellite-tracked drifters and state "originally deployed in the East Australian Current the buoys escaped from that region and travelled in the South Equatorial Current across the Indian Ocean," similar to the the mean flow field presented in Figure 7. The buoys traveled for 6 months from $100^{\circ} \mathrm{E}$ to locations east 
and just north of Madagascar. In moored current meter data just north of Madagascar, Quadfasel and Swallow [1986] have found 50-day period oscillations with evidence of such oscillations also in the drifters. From such oscillations, as well as from seasonal signals, transport variations from geostrophic computations could be expected for the SEC, although a seasonal signal was not present in the model results by Woodberry et al. [1989]. For the SEC, the Ekman transport is negligibly small compared to the geostrophic transport [Hastenrath and Greischar, 1991].

Our flow scheme shows the major southward flow from the Tropics east of Madagascar. The southward flow of $20 \mathrm{~Sv}$ east of Madagascar is in agreement with the estimate of $20.6 \mathrm{~Sv}$ from geostrophy at $23^{\circ} \mathrm{S}$ by Swallow et al. [1988]. From current meter moorings east of Madagascar at $23^{\circ} \mathrm{S}$, Schott et al. [1988] computed transports of $20.3 \mathrm{~Sv}+/-6.6 \mathrm{~Sv}$, similar to the geostrophic computations. From the moorings, no significant annual cycle could be detected despite significant variations of wind forcing over the subtropical Indian Ocean. From our few sections it cannot be established where the flow crosses the Mascarene Ridge and approaches Madagascar to form the East Madagascar Current.

The Mozambique Current is estimated here with a southward transport of only $5 \mathrm{~Sv}$ from sections at the northern and southern end of the Mozambique Channel. No newer sections in the channel were used. The result agrees with the findings of Saetre and Jorge da Siva [1984] that the circulation in the channel consists of a series of recirculation cells and with the 6 Sv from inverse calculations by $F u$ [1986]. The similarity is, however, not surprising as we used the same sections. Harris [1972] has estimated a Mozambique Current transport of $10 \mathrm{~Sv}$, while Hastenrath and Greischar [1991] found weak geostrophic surface currents in the annual mean directed southeastward, which were too weak to compute a reliable transport.

An open question is the transfer from the narrow and intense East Madagascar Current to the Agulhas Current, which was expected to exist only in a sporadic way by filaments and eddies [Lutjeharms et al., 1981; Lutjeharms, 1988]. In our schematic flow field (Figure 7) we show a wide band of $25 \mathrm{~Sv}$ moving to the west with a large meander. The inflow of water from east of Madagascar to the greater Agulhas system may therefore be accomplished by this more general, wide flow instead of the narrow, intense miniature western boundary current, the East Madagascar Current.

Gründlingh et al. [1991] have found evidence of a significant equatorward flux at the Madagascar Ridge (near $45^{\circ} \mathrm{E}$ ) from a section at $30^{\circ} \mathrm{S}$, which provided input of water from higher latitudes. They computed a net northward transport of about $14 \mathrm{~Sv}$ relative to 1000 dbar, while our schematic flow field shows a northward flow in the westernmost recirculation part of 10 to 20 Sv.
Our transport values for the Agulhas Current near $30^{\circ} \mathrm{S}$ vary considerably, in part caused by the fact that the Agulhas Current adheres to the coast and the shallow bottom depth below the core of the current [Pearce, 1977] considerably decreases the utility of geostrophic computations. Gründlıngh et al. [1991, p. 307] have summarized the results from the literature, where geostrophic calculations indicate a transport (relative to $1000 \mathrm{dbar}$ ) of around 20 to $40 \mathrm{~Sv}$ near $30^{\circ} \mathrm{S}$, while direct measurements of the flow yield much higher values of 40 to $80 \mathrm{~Sv}$. Gordon et al. [1987] have geostrophically calculated a high value of $50 \mathrm{~Sv}$ relative to $1500 \mathrm{dbar}$ off Durban $\left(30^{\circ} \mathrm{S}\right)$, possibly because the Agulhas Current executed a large offshore meander at the time and thus the bottom depth were greater below the current core. Our transport of $45 \mathrm{~Sv}$ at $30^{\circ} \mathrm{S}$ is close to the transport derived by Gordon et al. [1987]. Hellerman and Rosenstein [1983] have applied the Sverdrup relation to the curl of wind stress along $32^{\circ} \mathrm{S}$ in the Indian Ocean and obtained values of 40 to $60 \mathrm{~Sv}$. Schmitz [1996] has found the Agulhas Current system to be stable in time, even in density classes, and to be similar to the Gulf Stream system transports in similar density classes.

A strange feature presented in the transport is the meander of the westernmost recirculation cell, centered at about $38^{\circ} \mathrm{E}$ of $20 \mathrm{~Sv}$ (Figure 7), before merging with the Agulhas Current at about $32^{\circ} \mathrm{S}$. The diagonal sections off Africa show a second eastern core of the flow, while the northern extent is based only on one section and might not be a permanent feature. The root-meansquare variability of the sea surface topography from Geosat altimeter [Gründlıngh et al., 1991] shows a large amplitude east of the Agulhas Current at $32^{\circ} \mathrm{S}$, indicating large temporal variability in this area. Nevertheless, the western recirculation cell exists and its transport of $20 \mathrm{~Sv}$ is quite strong, probably caused by the topographic influence of the Madagascar Ridge.

The Indian Ocean has a vigorous overturning circulation consisting of net northward transport of deep and bottom water, with southward return of middepth thermocline, and near-surface waters. Toole and Warren [1993] have computed a northward transport across $32^{\circ} \mathrm{S}$ of about $27 \mathrm{~Sv}$ for the Circumpolar Deep Water below 2000 dbar and a southward transport of about 36 $\mathrm{Sv}$ above 2000 dbar, the difference of $9 \mathrm{~Sv}$ attributed to the throughflow from the Pacific to the Indian Ocean and to transport uncertainties, which they have estimated to account for up to $10 \mathrm{~Sv}$. Our schematic flow field shows only a net southward flow of $10 \mathrm{~Sv}$ in the upper $1000 \mathrm{~m}$ across the Indian Ocean. In a recent reexamination of the section used by Toole and Warren [1993] in density layers with the inclusion of the advective flux of dissolved silica by Robbins and Toole [1996], the southward flow in the upper layers is reduced to $22.6 \mathrm{~Sv}$. The southward flow in the upper two layers is 12.1 and $3.5 \mathrm{~Sv}$ in the third layer in which the 1000-m depth is located, thus resulting in less than $15 \mathrm{~Sv}$ southward transport in 
the upper $1000 \mathrm{~m}$. Beside the general uncertainty $(10$ Sv estimated by Toole and Warren [1993]), one reason for the difference to our estimate of $10 \mathrm{~Sv}$ is the fact that the southward flow within the Agulhas Current is difficult to estimate and that it might be possible that the Agulhas Current flow is a few sverdrups larger than computed here. Toole and Warren [1993] have applied ADCP velocity data as reference for three near-coastal station pairs, and the 0- to 2000-m Agulhas Current transport reduced from 85 to $70 \mathrm{~Sv}$, showing the uncertainties in estimating the Agulhas Current transport.

Our mean upper ocean, southward flow of $10 \mathrm{~Sv}$ above $1000 \mathrm{~m}$ is low compared to the $36 \mathrm{~Sv}$ by Toole and Warren [1993] above $2000 \mathrm{~m}$ which was reduced in the recalculation by Robbins and Toole [1996] to $22.6 \mathrm{~Sv}$ and less than $15 \mathrm{~Sv}$ above $1000 \mathrm{~m}$ and slightly lower than the $14 \mathrm{~Sv}$ net southward flow (of which only $4 \mathrm{~Sv}$ are in the layer above $12^{\circ} \mathrm{C}$ ) within the South Indian Ocean presented in a worldwide review of the thermohaline exchange by Schmitz [1995]. The varying transport numbers for the overturning cell possibly reflect both the uncertainties in the transport computations as well as existing variability.

Warren [1981b] has used a section at $18^{\circ} \mathrm{S}$ to describe a most prominent flow feature, namely an intense northward flow in the longitudes $75^{\circ}$ to $100^{\circ} \mathrm{E}$ with strong salinity maximum, weak shallow oxygen minimum, and somewhat strong oxygen maximum. For the AAIW in the South Indian Ocean, Fine [1993] has shown that the best ventilated AAIW (with respect to CFCs and oxygen) is observed in a compact anticyclonic gyre west of $72^{\circ} \mathrm{E}$. Toole and Raymer [1985] in turn have observed a net southward heat flux of $0.6 \mathrm{PW}$ in the Indian Ocean from a section at about $32^{\circ} \mathrm{S}$, indicating a net southward transport for the warm near-surface layers. All these findings fit the mean flow field derived here.

\section{Summary}

The aim of this investigation was to derive a mean transport field of the upper ocean of the South Indian subtropical gyre and to compare it with earlier observations. The presented flow field is of course an idealized version, not representing seasonal changes or the possible mesoscale water transfer by, for instance, filaments and eddies between the East Madagascar Current and the Agulhas Current. Although our 0- to 1000-m transport scheme (Figure 7) cannot directly be compared to the 0- to 2000-m flow field of Toole and Warren [1993] for the zonal RRS Charles Darwin section in November/December 1987 at $32^{\circ}$ to $35^{\circ} \mathrm{S}$, their transport stream function shows a weaker northward transport than ours west of $60^{\circ} \mathrm{E}$ and a stronger northward transport between $60^{\circ}$ and $73^{\circ} \mathrm{E}$. In the recalculation by $R o b$ bins and Toole [1996] of the northward transport west of $60^{\circ} \mathrm{E}$, it is almost $20 \mathrm{~Sv}$ larger than that of Toole and Warren [1993] and more comparable to our results. As our data are strongly affected by the two zonal sections at $32^{\circ} \mathrm{S}$ from July 1965 and April 1936 (Table 1), the differences described might be a seasonal signal, but the data are to sparse to investigate such a signal. Wyrtki's [1971] maps for 2-calendar-month periods do not resolve the central part of the South Indian Ocean in a manner to prove a seasonal signal. As seen in the comparison with the literature, different results exist for many geographical regions and the strength of the overturning cell, indicating variability of the gyre circulation. Nevertheless, the mean transport field presented here gives transport values for a mean state of the gyre with which single section results can be compared to investigate the seasonal changes and the general variability of the gyre transport field.

From our investigation it seems to be clear that in contrast to an earlier description of a long high-pressure ridge from the Agulhas Current reaching across the entire ocean into the Timor Sea with westward flow to the north of the ridge and eastward flow south of it [Wyrtki, 1973], a large part of the gyre circulation is concentrated in the southwestern and western part of the South Indian Ocean and south of Madagascar, probably caused in part by the topography. The total area influenced by the subtropical gyre in the South Indian Ocean shows a rectangular shape (Figure 7), different from the more triangular shape in the South Atlantic [Peterson and Stramma, 1991] probably caused by the cross-equatorial flow into the North Atlantic. The different gyre shapes from observations in the South Indian Ocean and South Atlantic are in agreement with recently derived results from a general circulation model [ $\mathrm{Ca}$ and Greatbatch, 1995]. Possible reasons for the rectangular shape might be the Pacific-Indian throughflow, and model results [Hirst and Godfrey, 1994] indicate such a mechanism and also the different shape of the wind stress [Hellerman and Rosenstein, 1983] could have an influence on the gyre shape.

Acknowledgments. This work has been supported by the Bundesministerium für Forschung and Technologie, Bonn, Germany (LS), and by the Foundation for Research Development, the Department of Environmental Affairs and the University of Cape Town in South Africa (JREL). JREL thanks in particular the Alexander Von Humboldt-Stiftung for a Humboldt Award for 1994 which made his stay at the Institut für Meereskunde in Kiel possible and his local hosts for their support, kindness, and hospitality. The data from the WDC-A were made available with the help of the German Oceanographic Data Center. We would like to acknowledge many helpful comments by Steve Rintoul, Chris Reason, and two reviewers and the work of all ship crews and scientists who collect hydrographic data and make them available to the oceanographic community through the data centers.

\section{References}

Belkin, I.M., and A.L. Gordon, Southern Ocean fronts from the Greenwich Meridian to Tasmania, J. Geophys. Res., 101, 3675-3696, 1996. 
Bennett, S.L., Where three oceans meet: The Agulhas Retroflection region, Ph.D. dissertation, 367 pp., Woods Hole Oceanogr. Inst., Woods Hole, Mass., 1988.

Caj, W., and R.J. Greatbatch, Compensation for the NADW outflow in a Global Ocean Circulation Model, J. Phys. Oceanogr., 25, 226-241, 1995.

Church, J.A., G.R. Cresswell, and J.S. Godfrey, The Leeuwin Current, in Poleward flows Along Eastern Ocean Boundaries, edited by S.J. Neshyba, C.N.K. Mooers, R.L. Smith, and R.T. Barber, pp. 230-254, Springer-Verlag, New York, 1989.

Clowes, A.J., An introduction to the hydrology of South African waters, Invest. Rep. 12, pp. 1-42, Fish. and Mar. Biol. Surv. Div., Cape Town, South Africa, 1950.

Fieux, M., C. Andrie, P. Delecluse, A.G. Ilahude, A. Kartavtseff, F. Mantisi, R. Molcard, and J.C. Swallow, Measurements within the Pacific- Indian Oceans throughflow region, Deep Sea Res., Part I, 41, 1091-1130, 1994.

Fine, R.A., Circulation of Antarctic Intermediate Water in the South Indian Ocean, Deep Sea Res., Part I, 40, 20212042, 1993.

Fu, L.-L., Mass, heat and freshwater fluxes in the South Indian Ocean, J. Phys. Oceanogr., 16, 1683-1693, 1986.

$\mathrm{Fu}$, L.L., and E.J. Christensen, TOPEX/Poseidon performance evaluated, Eos Trans. AGU, 74, 302, 1993.

Garzoli, S.L., and A.L. Gordon, Origins and variability of the Benguela Current, J. Geophys. Res., 101, 897-906, 1996.

Godfrey, J.S., The effect of the Indonesian throughflow on ocean circulation and heat exchange with the atmosphere: A review, J. Geophys. Res., 101, 12,217-12,237, 1996.

Gordon, A.L., Indian-Atlantic transfer of thermocline water at the Agulhas Retroflection, Scrence, 227, 1030-1033, 1985

Gordon, A.L., Interocean exchange of thermocline water, $J$. Geophys. Res., 91, 5037-5046, 1986.

Gordon, A.L., and E.J. Molinelli, Southern Ocean Atlas: Thermohaline and Chemical Distribution and the Atlas Data Set, 11 pp. and 233 plates, Columbia Univ. Press, New York, 1986.

Gordon, A.L., J.R.E. Lutjeharms, and M.L. Gründlingh, Stratification and circulation at the Agulhas Retroflection, Deep Sea Res., Part A, 34, 565-599, 1987.

Gründlingh, M.L., Two contra-rotating eddies of the Mozambique Ridge Current, Deep Sea Res., Part A, 36, 149-153, 1989.

Gründlingh, M.L., R.A. Carter, and R.C. Stanton, Circulation and water properties of the southwest Indian Ocean, Spring 1987, Prog. Oceanogr., 28, 305-342, 1991.

Harris, T.F.W., Sources of the Agulhas Current in the spring of 1964, Deep Sea Res., 19, 633-650, 1972.

Hastenrath, S., and L. Greischar, The monsoonal current regimes of the tropical Indian Ocean: Observed surface flow fields and their geostrophic and wind-driven components, J. Geophys. Res., 96, 12,619-12,633, 1991

Hellerman, S., and M. Rosenstein, Normal monthly wind stress over the World Ocean with error estimates, J. Phys. Oceanogr., 13, 1093-1104, 1983.

Heydorn, A.E.F., et al., Ecology of the Agulhas Current region: An assessment of biological responses to environmental parameters in the South- West Indian Ocean, Tran. R. Soc. S. Afr., 43, 151-190, 1978.

Hirst, A.C., and J.S. Godfrey, The response to a sudden change in Indonesian throughflow in a global ocean GCM, J. Phys. Oceanogr., 24, 1895-1910, 1994.

Lutjeharms, J.R.E., A quantitative assessment of year-toyear variability in water movement in the south-west Indian Ocean, Nalure, 239, 59-69, 1972.
Lutjeharms, J.R.E., The Agulhas Current system during the Northeast Monsoon Season, J. Phys. Oceanogr., 6, 665$670,1976$.

Lutjeharms, J.R.E., Die Subtropiese Konvergensie en Agulhasretrofleksie- vaart (SCARC), S. Afr. J. Sci., 83, 454456, 1987.

Lutjeharms, J.R.E., Remote sensing corroboration of retroflection of the East Madagascar Current, Deep Sea Res., Part A, 35, 2045-2050, 1988.

Lutjeharms, J.R.E., The exchange of water between the South Indian and the South Atlantic, in The South Atlantic: Present and Past Circulation, edited by G. Wefer, W.H. Berger, G. Siedler, and D. Webb, pp. 125-162, Springer-Verlag, New York, 1996.

Lutjeharms, J.R.E., and J. Cooper, Interbasin leakage through Agulhas Current filaments, Deep Sea Res., Part I, 43, 213-238, 1996.

Lutjeharms, J.R.E., and H.R. Valentine, Southern Ocean thermal fronts south of Africa, Deep Sea Res., Part A, 31, 1461-1475, 1984.

Lutjeharms, J.R.E., and R.C. Van Ballegooyen, Topographic control in the Agulhas Current system, Deep Sea Res., Part A, 31, 1321-1337, 1984.

Lutjeharms, J.R.E., and R.C. Van Ballegooyen, The retroflection of the Agulhas Current, J. Phys. Oceanogr., 18, 1570-1583, 1988.

Lutjeharms, J.R.E., N.D. Bang, and C.P. Duncan, Characteristics of the currents east and south of Madagascar, Deep Sea Res., Part A, 28, 879-899, 1981.

Mantyla, A.W., and J.L. Reid, On the origins of deep and bottom waters of the Indian Ocean, J. Geophys. Res., 100, 2417-2439, 1995.

McCartney, M.S., Subantarctic Mode Water, in $A$ Voyage of Discovery, edited by M.V. Angel, pp. 103-119, Pergamon, Terrytown, N Y., 1977

McCartney, M.S., The subtropical recirculation of Mode Waters, J. Mar. Res., 40, suppl., 427-464, 1982.

Meyers, G., R.J. Bailey, and A.P. Worby, Geostrophic transport of Indonesian throughflow, Deep Sea Res., Part I, 42, 1163-1174, 1995.

Michaelis, G., Die Wasserbewegung an der Oberfläche des Indischen Ozeans im Januar und Juli, Veröff. Inst. Meereskunde Univ. Berlın, A8, 1-32, 1923.

Möller, L., Die Zirkulation des Indischen Ozeans aufgrund von Temperatur- und Salzgehaltstiefenmessungen und Oberflächenstrombeobachtungen, Veröff. Inst. Meereskunde Univ. Berlin, A21, 1-48, 1929.

Moore, A.F., and C.J.C. Reason, The response of a global ocean general circulation model to climatological surface boundary conditions for temperature and salinity, J. Phys. Oceanogr., 23, 300-328, 1993.

Naeije, M.C., E. Wisse, R. Scharroo, and K.F. Wakker, Ocean dynamics from the ERS-1 35-day repeat mission, in Proceedings Second ERS-1 Symposium, Eur. Space Agency Spec. Publ., ESA SP-361, 501-506, 1994.

Nof, D., Choked flows from the Pacific to the Indian Ocean, J. Phys. Oceanogr., 25, 1369-1383, 1995.

Paech, H., Die Oberflächenströmungen um Madagascar in ihrem jährlichen Gang, Veröff. Inst. Meereskunde Univ. Berlin, A 16, 1-39, 1926.

Park, Y.-H., and L. Gamberoni, Large scale circulation and its variability in the South Indian Ocean from TOPEX/ POSEIDON altimetry, J. Geophys. Res., 100, 24,91124,929, 1995.

Park, Y.-H., and L. Gamberoni, Cross-frontal exchange of Antarctic Intermediate Water and Antarctic Bottom Water in the Crozet Basin, Deep Sea Res., Part A, in press, 1996. 
Park, Y.-H., L. Gamberoni, and E. Charriaud, Frontal structure and transport of the Antarctic Circumpolar Current in the South Indian Ocean sector, $40-80^{\circ} \mathrm{E}$, Mar. Chem., 35, 45-62, 1991.

Park, Y.-H., L. Gamberoni, and E. Charriaud, Frontal structure, water masses, and circulation in the Crozet Basin, J. Geophys. Res., 98, 12,361-12,385, 1993.

Pearce, A.F., Some features of the upper $500 \mathrm{~m}$ of the Agulhas Current, J. Mar. Res., 35, 731-751, 1977.

Peterson, R.G., and L. Stramma, Upper-level circulation in the South Atlantic Ocean, Prog. Oceanogr., 26, 1-73, 1991.

Quadfasel, D.R., and J.C. Swallow, Evidence for 50-day period planetary waves in the South Equatorial Current of the Indian Ocean, Deep Sea Res., Part A, 33, 1307-1312, 1986.

Read, J.F., and R.T. Pollard, Structure and transport of the Antarctic Circumpolar Current and Agulhas Return Current at $40^{\circ} \mathrm{E}, J$. Geophys. Res., 98, 12,281-12,295, 1993.

Reason, C.J.C., R.J. Allan, and J.A. Lindsay, Evidence for the influence of remote forcing on interdecadal variability in the southern Indian Ocean, J. Geophys. Res., 101, 11,867-11,882, 1996.

Reid, J., On the total geostrophic circulation of the North Atlantic Ocean: Flow patterns, tracers and transports, Prog. Oceanogr., 33, 1-92, 1994.

Robbins, P.E., and J.M. Toole, The dissolved silica budget as a constraint on the meridional overturning circulation of the Indian Ocean, Deep Sea Res., Part I, in press, 1996.

Saetre, R., and A. Jorge da Silva, The circulation of the Mozambique Channel, Deep Sea Res., Part A, 31, 485$508,1984$.

Schmitz, W.J., Jr., On the interbasin-scale thermohaline circulation, Rev. Geophys., 33, 151-173, 1995.

Schmitz, W.J., Jr., On the eddy field in the Agulhas area, with global implications, J. Geophys. Res., 101, 16,25916,271, 1996.

Schott, F., and M. Fieux, The Somali Current in autumn 1984, before the onset of the north-east monsoon, Nature, $315,50-52,1985$.

Schott, F., M. Fieux, J. Kindle, J. Swallow, and R. Zantopp, The boundary currents east and north of Madagascar, 2, Direct measurements and model comparison, J. Geophys. Res., 93, 4963-4974, 1988.

Smith, R.L., A. Huyer, J.S. Godfrey, and J.A. Church, The Leeuwin Current off western Australia, J. Phys. Oceanogr., 21, 322-345, 1991.

Stramma, L., The South Indian Ocean Current, J. Phys. Oceanogr., 22, 421-430, 1992.

Stramma, L., and R.G. Peterson, The South Atlantic Current, J. Phys. Oceanogr., 20, 846-859, 1990.

Stramma, L., R.G. Peterson, and M. Tomczak, The South Pacific Current, J. Phys. Oceanogr., 25, 77-91, 1995.

Sverdrup, H.U., M.W. Johnson, and R.H. Fleming, The Oceans: Their Physics, Chemistry and General Biology, 1087 pp., Prentice-Hall, Englewoods Cliffs, N. J., 1942.
Swallow, J., M. Fieux, and F. Schott, The boundary currents east and north of Madagascar, 1, Geostrophic currents and transports, J. Geophys. Res., 93, 4951-4962, 1988.

Tomczak, M., and J.S. Godfrey, Regional Oceanography: An Introduction, 422 pp., Pergamon, Tarrytown, N. Y., 1994.

Tomczak, M., and D.G.B. Large, Optimum multiparameter analysis of mixing in the thermocline of the eastern Indian Ocean, J. Geophys. Res., 94, 16,141-16,149, 1989.

Toole, J.M., and M.E. Raymer, Meridional heat and fresh water budgets of the South Indian Ocean - Revisited, Deep Sea Res., Part A, 32, 917-928, 1985.

Toole, J.M., and B.A. Warren, A hydrographic section across the subtropical South Indian Ocean, Deep Sea Res., Part I, 40, 1973-2019, 1993.

Van Ballegooyen, R.C., M.L. Gründlingh, and J.R.E. Lutjeharms, Eddy fluxes of heat and salt from the southwest Indian Ocean into the southeast Atlantic Ocean: A case study, J. Geophys. Res., 99, 14,053-14,070, 1994.

Warren, B.A., Deep circulation of the World Ocean, in Evolution of Physical Oceanography, edited by B.A. Warren and C. Wunsch, pp. 6-41, MIT Press, Cambridge, Mass., 1981a.

Warren, B.A., Transindian hydrographic section at lat. $18^{\circ} \mathrm{S}$ : Property distributions and circulation in the South Indian Ocean, Deep Sea Res., Part A, 28, 759-788, 1981b.

Woodberry, K.E., M.E. Luther, and J.J. O'Brien, The winddriven seasonal circulation in the southern tropical Indian Ocean, J. Geophys. Res., 94, 17,985-18,002, 1989.

Wüst, G., Proposed International Indian Ocean Oceanographic Expedition, 1962 - 1963, Deep Sea Res., 6, 245249, 1960

Wüst, G., The Stratosphere of the Atlantic Ocean. Scientific Results of the German Atlantic Expedition of the Research Vessel "Meteor" 1925-27 (English translation), vol. VI, section I, 112 pp., Amerind, New Dehli, India, 1978.

Wyrtki, K., Occanographic Atlas of the International Indian Ocean Expedition, 531 pp., Nat. Sci. Found. Washington D.C., 1971.

Wyrtki, K., Physical oceanography of the Indian Ocean, in The Biology of the Indian Ocean, edited by B. Zeitzschel and S.A. Gerlach, pp. 18-36, Springer-Verlag, New York, 1973.

J. R. E. Lutjeharms, Department of Oceanography, University of Cape Town, 7700 Rondebosch, South Africa. (email: johann@physci.uct.ac.za)

L. Stramma, Institut für Meereskunde an der Universität Kiel, Düsternbrooker Weg 20, 24105 Kiel, Germany. (e-mail: lstramma@ifm.uni-kiel.de)

(Received August 1, 1995; revised October 16, 1996; accepted October 23, 1996.) 